\title{
Changes in bird assemblages because of vegetation homogenisation in communal livestock systems
}

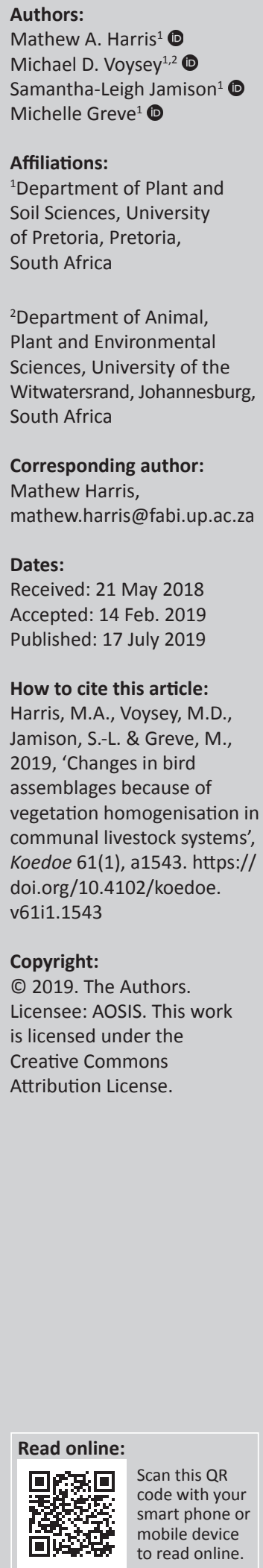

Protected areas are intended to promote biodiversity representation and persistence; yet, whether they are effective in degraded landscapes where much of the original vegetation structure remains intact has received relatively little attention. We test whether avian assemblages in communal rangelands in savannas differ from savannas supporting a full complement of native herbivores and predators. Birds were surveyed in 36 transect counts conducted over 18 days. We also compare the vegetation structure between the two land-use types to assess whether differences in bird assemblages could be attributed to changes in vegetation structure. Bird assemblages were richer, had greater abundances and different compositions inside protected areas than rangelands. The median body mass of birds was larger inside than outside protected areas, and rangelands supported fewer grassland specialists, but more closed-canopy specialists. However, no differences in feeding guild composition were found between protected areas and communal rangelands. Additionally, vegetation structure, but not richness, differed between protected areas and communal rangelands: communal rangelands had higher densities of woody vegetation and shorter grass height than the protected areas. Our findings suggest that the altered vegetation structure in communal grazing camps has led to changes in the species richness and composition of bird communities and has been selected by closed-canopy specialists at the cost of open grassy specialists. Hunting in communal rangelands is likely to have resulted in the loss of large birds and in reductions in bird abundance in the rangelands. Therefore, land-use management that does not lead to irreversible landscape transformation can nevertheless result in changes in the diversity, composition and functioning of native assemblages.

Conservation implications: Savanna landscapes that are degraded, but not transformed, support fewer bird species, fewer open habitat specialists and smaller birds because of vegetation homogenisation.

Keywords: avifauna; encroachment; functional composition; hunting; vegetation structure; conservation.

\section{Introduction}

It has been estimated that $52 \%$ of the Earth's surface has been modified by human activities such as food production, timber plantations and urban areas (Roser \& Ritchie 2018). This has resulted in alterations in the structure and functioning of these systems (Chown 2010; Foley et al. 2005). With human population growth unlikely to stabilise in the 21st century (Gerland et al. 2014), the protection of natural habitats remains paramount for the conservation of biodiversity and the ecosystem services they provide (Dudley, Hockings \& Stolton 2010). Even where primary components of habitats have been retained, unprotected landscapes have often been degraded and community assemblages have been altered via either direct (e.g. harvesting) or indirect (e.g. light pollution) impacts by humans, or both (Chown 2010; Gaston et al. 2008; Longcore \& Rich 2004). Therefore, the designation and maintenance of protected areas (PAs) remains a key strategy for protecting biodiversity from such pressures globally (Gaston et al. 2008; Joppa \& Pfaff 2009; Pimm et al. 2014).

A substantial proportion ( $40 \%$ ) of the estimated annual global conservation budget is utilised for establishing, maintaining and improving PAs (Balmford et al. 2015; Chape et al. 2005; James, Gaston \& Balmford 1999; Waldron et al. 2013). Yet, despite the enormous investment in PAs annually ( $\$ 10$ billion, Waldron et al. 2013), only a limited number of studies have explicitly attempted to assess PA ecological effectiveness (e.g. Coetzee, Gaston \& Chown 2014; Gray et al. 2016; Greve et al. 2011), with most studies evaluating PA effectiveness in terms of how well the PA prevents landscape cover change (e.g. Andam et al. 2008; Joppa, Loarie \& Pimm 2008). 
However, this measure serves only as a proxy for PA performance, as it cannot capture the implications of landuse change for biodiversity features (Coetzee et al. 2014), especially when considering that the effectiveness of any given PA at conserving features of biodiversity is context specific and often depends on the extent and intensity of local pressures, for example fires or poaching. Thus, individual PAs often show localised differences in measures of their ecological effectiveness (Caro et al. 2009; Gaston et al. 2008; Gray et al. 2016; Laurance et al. 2012).

The best measure of PA ecological effectiveness would be a comparison of the current overall biodiversity status for a PA with the biodiversity status that would have been if the PA had not been designated (Coetzee et al. 2014). However, a comparison of this nature cannot be achieved, as it is impossible to know what the biodiversity status of a particular area would have been had a PA not been established. Thus, an alternative is to assess biodiversity before and after PAs were established; but baseline data quantifying biodiversity before PA declaration are rare (see Laurance et al. 2011; Wegge et al. 2009). As a result, assessments of the effectiveness of PAs are assessed differently. For example PA effectiveness is measured based on management decisions and their effects on biodiversity within PAs. Others compare biodiversity features within PAs to areas in the immediate vicinity or to non-protected areas with similar characteristics, that is, using space for time substitutions (Geldmann et al. 2013). Essentially, biodiversity features of areas inside PAs are compared to biodiversity features outside PAs, as these areas would be similar were it not for their land-use designation (Coetzee et al. 2014; Gray et al. 2016; Greve et al. 2011). The assumption is that the areas inside PAs would have experienced land-use changes similar to those outside the PAs, had the PA not been established, and is thus used as a proxy measure of PA ecological effectiveness.

The ecological effectiveness of PAs can be considered at different hierarchical and taxonomic levels of organisation of biodiversity, for example species (abundance), communities (richness and assemblage composition) and the functions they perform (Gaston et al. 2006). To maintain biodiversity, PAs must display representation, that is, support a diversity of species (or functions) within their boundaries, and they must allow for persistence of biodiversity and function, that is buffer biodiversity from perturbations (Margules \& Pressey 2000) such as climate change (Stevens et al. 2016) or exploitation (Cullen, Bodmer \& Pádua 2000).

The literature on quantifying PA ecological effectiveness has often focused on comparing biodiversity in PAs to that of adjacent heavily transformed areas, for example agricultural fields, plantations and human settlements (Gardner et al. 2007; Jackson, Evans \& Gaston 2009; Hoffmann et al. 2010; Greve et al. 2011; Geldmann et al. 2013). The impacts on biodiversity of areas that have undergone comparatively little habitat transformation remain less well understood (see Greve et al. 2011; Rayner et al. 2014; Sinclair, Mduma \&
Arcese 2002). Therefore, this study aims to compare the biodiversity features, species assemblages and functional composition of avian fauna within and outside neighbouring PAs, across what once was a homogenous vegetation type within the savanna biome. The land-use outside these PAs is communal rangelands (CRs), which are nearly completely uncultivated semi-natural rangelands, where collective ranching of livestock takes place (Palmer \& Bennett 2013). Land-use within the PAs is categorised by minimal anthropogenic disturbance, with the areas being managed for the persistence of biodiversity. The CRs are extractive reserves where resources such as firewood are harvested, and the native herbivores have largely been replaced with livestock, mainly cattle. Several different ecological measures are compared between PAs and the surrounding CRs: species richness, abundance, species assemblage composition and functional differences. This work thus provides valuable insights into understanding how well PAs conserve various measures of biodiversity compared to slightly degraded unprotected habitats. It aids in the growing understanding of how PAs and their surrounding matrix areas can function in unison to conserve various biodiversity features and highlights some of the pressures faced by biodiversity in and around the exemplar Kruger National Park.

\section{Methods and materials Study region}

Surveys were conducted in the Lowveld savanna of South Africa around the Orpen region of the Kruger National Park and Manyeleti Game Reserve, and adjacent CRs belonging to the Mnisi Tribal Authority (Figure 1). Three sites were chosen for each of two different land-use types: PAs and CRs. Of the three study sites in the PAs, two were in the Kruger National Park - one near the Orpen Rest Camp and the other in the Kingfisherspruit section - and the third in the Manyeleti Game Reserve near the Khokomya dam. Communal rangeland sites were located south-west of Kruger and Manyeleti and consisted of three cattle grazing camps: Shorty, Athol and Gottenburg. Each CR site is associated with a village and stocked with varying densities of cattle, and occasionally goats are allowed into the camps to browse (Table 1-A1). Unlike the surrounding villages, the CR grazing camps have experienced no habitat loss per se. They are solely used for grazing and almost exclusively support native vegetation. We therefore consider the CRs to be degraded and not transformed (Rouget et al. 2006).

All sites were located in the Gabbro Grassy Bushveld vegetation type, characterised by rich clayey soils, opensavanna, dense low-growing grass cover and scattered trees and shrubs (Mucina \& Rutherford 2006). All sites in PAs and CRs were selected to occur on the Timbavati Gabbro intrusion; this was confirmed by using Google Earth imagery (Figure 1). All site selection was primarily based on the presence of entry gates within CRs and waterpoints within PAs. Communal rangeland sites were selected based on whether tribal leaders granted the researchers access to their rangeland. PA site selection was chosen based on proximity to the Orpen 

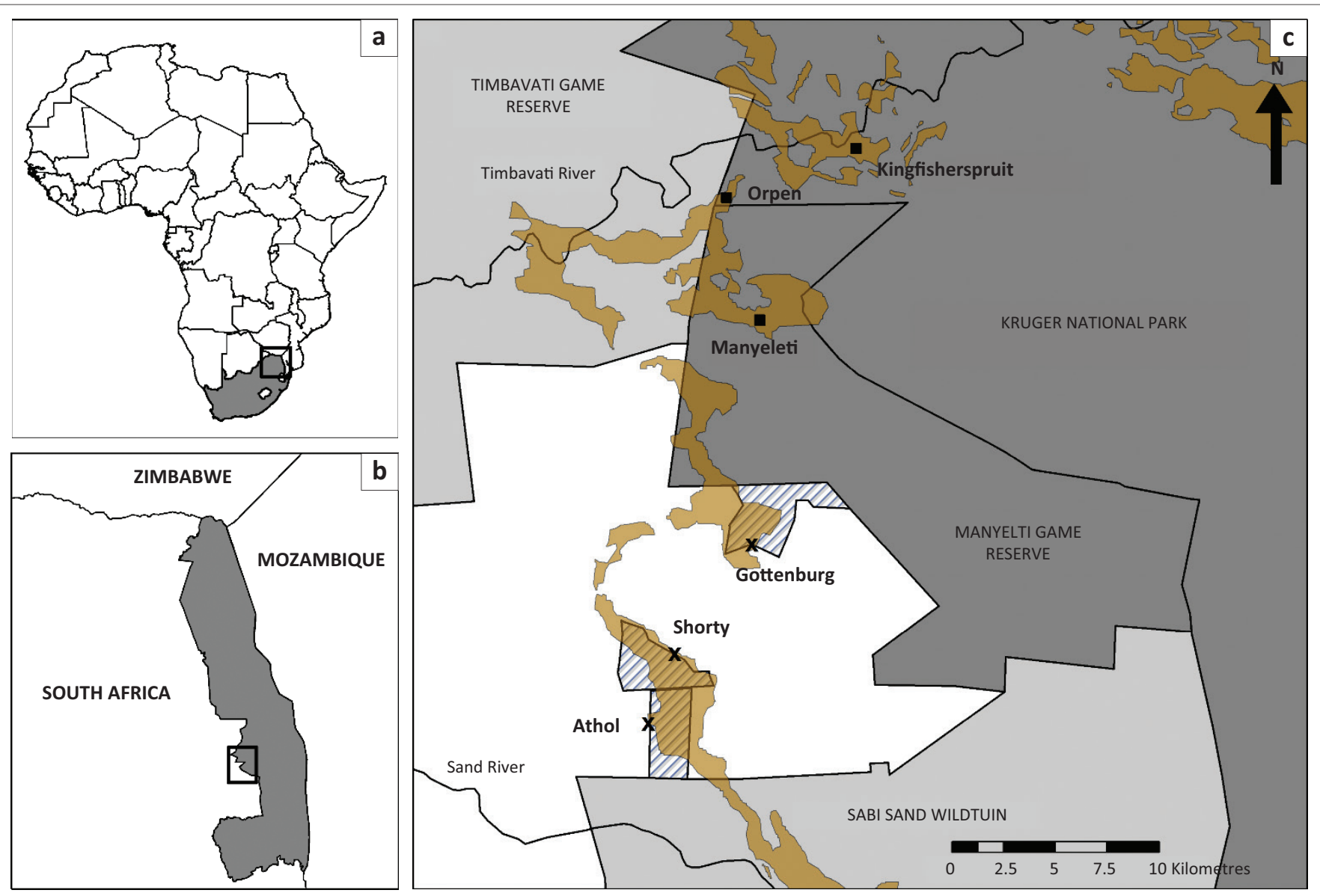

FIGURE 1: Map showing the study area. (a) South Africa, (b) the north-eastern region of South Africa around the Kruger National Park (in grey) and (c) the locations of the three sites within the protected areas (Kruger National Park and Manyeleti Game Reserve) and outside the protected areas in the communal rangelands (Athol, Gottenburg and Shorty). The brown colour represents the extent of Gabbro soil intrusion in the area (Mpumalanga Department of Agriculture and Land Administration 1997). At each site, three transects were set up to sample avian diversity and vegetation characteristics. Dark grey areas represent government-run protected areas, light grey areas represent privately run protected areas and areas in grey hatching represent cattle camps in communal rangelands used in this study. Areas in white represent communally managed areas.

gate to ensure bird surveys were completed before 08:30 each morning. The direction of each transect varied depending on the positions of the gates (in CRs), the position of roads (in PAs) and to ensure positioning on the Gabbro soils.

The sites in the PAs represent relatively pristine ecosystems that harbour a full set of native herbivores, and regular fires are used as a management strategy. In contrast, CRs are characterised by natural vegetation where wild herbivores have been excluded and replaced with cattle. Low densities of goats occasionally stray into the camps, where their activities are restricted to areas close to the gates. Fire has largely been excluded from CRs, although some wood extraction takes place in the area.

The maximum distance between two study sites, namely Kingfisherspruit and Athol, was $30 \mathrm{~km}$ and the minimum distance was $4 \mathrm{~km}$ (between Athol and Shorty); thus all sites experience similar climatic conditions.

\section{Bird sampling}

All surveys were conducted during January and February 2017; therefore, our findings are representative of summer bird communities. At each of the six sites, three 1-km transects were laid out (Bibby, Jones \& Marsden 2000). At each site, the three transects sampled radiated outwards from a focal area of high herbivore activity (i.e. a water point within PAs and a gate from which cattle could actively enter the CRs) (Figure 1-A1). The starting points of transects within a site were at least $150 \mathrm{~m}$ apart from one another, and distances between transects increased as one moved further along the transects, as the transects radiated out from one another (Figure 1-A1). The transects were set up to radiate out from focal points, which experience high herbivore activity, to areas of lower herbivore activity, to ensure the highest possible similarity in herbivore density for all transects.

Each transect was walked twice on two different mornings and all birds along the transects were recorded. Before starting a transect, the observers waited at the start of the transect for 2 minutes to allow birds to become accustomed to their presence (Bibby et al. 2000). Then a steady pace was walked for the length of the transect (Bibby et al. 2000). The time it took to walk each transect was standardised to not exceed 60 minutes to ensure an equal sampling effort. The average time per transect was 51 minutes. A compass was used to ensure a constant direction was maintained, 
especially when the surrounding vegetation became thick. All bird observations were made by two observers (M.A.H. and M.D.V.). All birds that were seen or heard on either side of the transect were recorded (Bibby et al. 2000). The distance from the observer to the bird was visually estimated and the angle between the bird and the transect was measured using a compass (Bibby et al. 2000). Both observers' estimates were used to come to an estimated consensus on distance and angle. When birds of the same species occurred in parties, all individuals of the party were counted and recorded as one sighting, with the distance and angle being estimated to the centre of the party to ensure independence of observations (Bibby et al. 2000). The estimated distance from the observer and the angle from the transect line were used to calculate the perpendicular distance from the bird to the transect using Pythagoras theorem (Bibby et al. 2000). Only sightings within the $50 \mathrm{~m}$ limit of the transect line were retained (Bibby et al. 2000).

Surveys were conducted on mornings between 06:00 and 08:30, during peak bird activity and vocalisation. Surveys were only conducted in mild weather; no transects were surveyed on mornings with high winds or heavy rain. Birds flying over the transect were not recorded (Bibby et al. 2000). The order of transect surveys was randomised as far as possible by land-use type. In addition, repeat samples of the same transect were temporally spaced out over the sampling period (i.e. not conducted on consecutive mornings) between the sampling dates of 09 January and 02 February 2017.

\section{Vegetation sampling}

The composition of avian assemblage in South African savannas is affected by differences in grass and woody vegetation structure (Hudson \& Bouwman 2007; Krook, Bond \& Hockey 2007; Skowno \& Bond 2003). Thus, structural vegetation attributes were recorded for the first $500 \mathrm{~m}$ of each transect. Because of time constraints, only the first $500 \mathrm{~m}$ of each transect could be sampled. Structural changes in vegetation along the transects happened mostly at the start of the transects close to the water source or gate so that the vegetation measures generated within the first $500 \mathrm{~m}$ were fairly representative of the entire transect (Figures 2-A1 and Figure 3-A1). Every $10 \mathrm{~m}$ along the transect, a $0.5 \mathrm{~m} \times 0.5 \mathrm{~m}$ plot was placed on the ground and the maximum leaf table height (the height of the tallest grass leaf material) of each grass species was recorded, from which the average maximum leaf table height per transect was calculated. In addition, at each plot along the transect all woody individuals greater than $0.5 \mathrm{~m}$ in height, within a $2 \mathrm{~m}$ radius from the centre of the plot, were recorded, from which the average density of woody individuals per transect was calculated (Voysey 2018).

\section{Analyses}

\section{Sampling adequacy and species diversity}

The data for the two repeat surveys of each transect were pooled before all analyses. To determine sampling adequacy, transect-based species accumulation curves were constructed (Gotelli \& Colwell 2001). Jackknife 1 and Jackknife 2 estimated species richness of the PAs and CRs were calculated to get an estimate of the total species richness by accounting for undetected species.

Generalised linear mixed models (GLMMs) were used to test whether land-use type, that is PAs versus CRs, affect the species richness and overall abundance of birds. Structural vegetation variables (average maximum grass leaf table height of the first $500 \mathrm{~m}$ of the transect, and average density of woody vegetation above $0.5 \mathrm{~m}$ in height of the first $500 \mathrm{~m}$ of the transect) were incorporated as predictor variables in the models. Interaction terms of the two structural vegetation variables with land-use were included in the models to determine if their effect depended on land-use. Site was included as a random variable (McCulloch 1996). Models were fitted using a Poisson distribution and a log-link function (Zuur et al. 2009). A full model using all predictor variables was created (global model), from which the best subset model, based on the lowest Akaike information criterion (AIC), was obtained using the dredge function in $\mathrm{R}$ (Burnham \& Anderson 2002).

Bias in abundance or density estimates may occur because of differences in species detectability between land-use types; we thus tested whether land-use influenced species detectability (Coetzee \& Chown 2016; Greve et al. 2011; Thomas et al. 2010) (Figures 4-A1 and 5-A1). Since several species were recorded rarely, it was impossible to create species detectability curves for every species. Therefore, a surrogate species approach, where similar species were grouped together, was used (Coetzee \& Chown 2016; Greve et al. 2011; Thomas et al. 2010), using the same seven groups identified for the region by Coetzee and Chown (2016). A species detectability curve could not be fit for surrogate group 1 in CRs, that is large-bodied ground nesters, because only two observations were made in CRs.

A Pearson correlation analysis was conducted to assess the goodness of fit between true and estimated density for each surrogate bird group, in each of the land-use types, following Coetzee and Chown (2016). This enabled us to determine if there were any differences in detectability between land-uses or the different surrogate bird species groups.

\section{Assemblage composition}

To compare bird species composition between the two landuse types, three approaches were used. First, the number of species that were shared and were unique to each land-use was calculated. Secondly, differences in bird composition between PAs and CRs were explored using non-metric multidimensional scaling (nMDS) plots based on species identity and abundance per transect. Species recorded only once were removed and the remaining data were plotted using a BrayCurtis distance measure. Random restarts were used to obtain the best possible fit for the data in reduced dimensions. A stress plot was created to determine if the representation of 
the data in reduced dimensions was good or not. Finally, a permutational multivariate analysis of variance (PERMANOVA) was used to test whether land-use was a good predictor of bird species composition.

\section{Functional characteristics}

Body mass is an important characteristic of animals that correlates with many traits, such as reproduction rates and population densities (Brose et al. 2017), and often determines the level of exploitation experienced by a species (Brose et al. 2017; Cullen et al. 2000; Pimm et al. 2014). Therefore, we tested whether the median body mass of birds differed between land-uses (PAs vs. CRs). As the body mass distribution for birds is typically skewed, the median body mass is a more appropriate measure than the mean for analysing body mass data of assemblages (Meiri \& Thomas 2007). Therefore, median bird mass was calculated per transect-based on the mass of each individual bird observed per transect in both surveys. Adult body masses for all species were obtained from Greve et al. (2008). We then tested whether median bird body mass per transect differed between land-use types (i.e. PAs vs. CRs) using a GLMM that was fitted with a Gaussian distribution and a log-link function (Zuur et al. 2009). Site was included as a random variable. Woody and grass structural vegetation attributes were additionally included as predictor variables in the model. The best subset model selection followed the same procedure as above (Zuur et al. 2009).

Next, birds were assigned to one of five feeding guilds (carnivore, frugivore, mixed feeder, granivore or insectivore) based on diet information that was obtained from Hockey, Dean and Ryan (2005) and categorised by Jamison (2017). Additionally, species were categorised into four habitat preference classes based on whether they spend the majority of their time in open grassy areas, closed wooded areas or a mixture of both of these habitats. Category 1 represents grassland/open-savanna specialists and category 4 represents closed-savanna/thicket/forest specialists. Category 2 and 3 species associate with a mixture of the two types of habitats, however, associating with more open (category 2) or more closed (category 3) habitats, respectively. This categorisation was based on habitat association information from Hockey et al. (2005), following the categorisation of Péron and Altwegg (2015), except that categories were scaled the other way around.

Compositional analyses (Aitchison 1982) were performed to test whether the compositions of the feeding guilds and habitat preference categories differed between PAs and CRs. In this analysis, each transect was treated as a vector (i.e. all five classes of feeding guilds [or habitat preference categories] of one transect represented a single composition). The composition, that is the proportion of each class within feeding guilds (or habitat preference categories), was calculated for each transect, per land-use type, within a multi-dimensional space, rather than as an arithmetic mean of each class individually. Separate cluster analyses were conducted for feeding guild and habitat preference category compositions to compare how similar PA and CR transects were in terms of their feeding guild and habitat preference category compositions, respectively. Cluster analyses grouped transects based on the similarity of their functional compositions in the multi-dimensional Euclidean space.

\section{Vegetation structure}

General linear mixed models (LMMs) were run to assess whether tree density and maximum leaf table height differed between land-use types (Zuur et al. 2009). For these analyses, tree density and maximum leaf table height were averaged per transect prior to analyses. Site was included as a random variable.

All analyses were conducted in R, version 3.2.6 (R Core Team 2018), using the following packages for the various analyses: vegan (Oksanen et al. 2017) for rarefaction curves, species richness estimates and nMDS plot; Distance (Miller 2017) for detection curves and abundance estimates; lme4 (Bates et al. 2015) for LMMs and GLMMs; MuMIn (Barton 2017) for best subset model based on AIC; and compositions (Van den Boogaart, Tolosana \& Bren 2014) for the compositional analysis framework.

\section{Ethical considerations}

The authors do not have any ethical considerations that need to be disclosed for the publication of this article.

\section{Results \\ Species diversity}

The transect-based species accumulation curves for both PA and $\mathrm{CR}$ transects began flattening off, though neither reached an asymptote (Figure 6-A1), indicating that several species remained unsampled. Therefore, the raw species richness values for both PAs and CRs should be treated with some caution. Recorded species richness was larger for PAs (94) than for the CRs (74). Jackknife species richness estimates indicated that estimated total species richness was higher within PAs (Jackknife 1: $124.2 \pm 11.7$; Jackknife 2: 137.1) than within CRs (Jackknife 1: $105.1 \pm 13.1$; Jackknife 2: 124.8).

A significant correlation was seen between the observed density and modelled density of birds for each surrogate group and each land-use (Pearson's $r=0.989 ; p<0.001$; $n=13$ ) (Figure 7-A1). As a result, we consider the influence of species detectability and the detectability between land-uses as negligible in our study; thus, abundances were not adjusted for detectability (see Coetzee \& Chown 2016; Greve et al. 2011; Thomas et al. 2010).

The effect of land-use type on species richness was significant, but dependent on grass height (Table 1). Species richness did not change with grass height in PAs, but in CRs it increased 
TABLE 1: Results from the best subset generalised linear mixed effects model assessing the effect of land-use types (protected areas versus communal rangelands) on raw avian species richness, while taking vegetation structure variables (maximum grass leaf table height and the density of woody vegetation $>0.5 \mathrm{~m}$ ) into consideration.

\begin{tabular}{|c|c|c|c|c|c|c|c|}
\hline Variable & Level & Estimate & SE & $z$ & $p$ & SD & Variance \\
\hline \multicolumn{8}{|l|}{ Fixed effects } \\
\hline Woody density & - & -1.165 & 0.599 & -1.943 & ns & - & \\
\hline Maximum grass height & - & 8.215 & 3.343 & 2.533 & $*$ & - & \\
\hline Land-use & Protected $>$ Rangeland & 1.266 & 0.405 & 3.125 & $* *$ & - & \\
\hline Land-use $\times$ maximum grass height & - & -9.012 & 3.328 & -2.708 & $* *$ & - & \\
\hline \multicolumn{8}{|l|}{ Random effect } \\
\hline (1|Site) & - & - & - & - & - & 0.00 & 0.00 \\
\hline
\end{tabular}

$\mathrm{SE}$, standard error; SD, standard deviation; ns, not significant.

$*, p<0.05 ; * *, p<0.01 ; * * *, p<0.001$

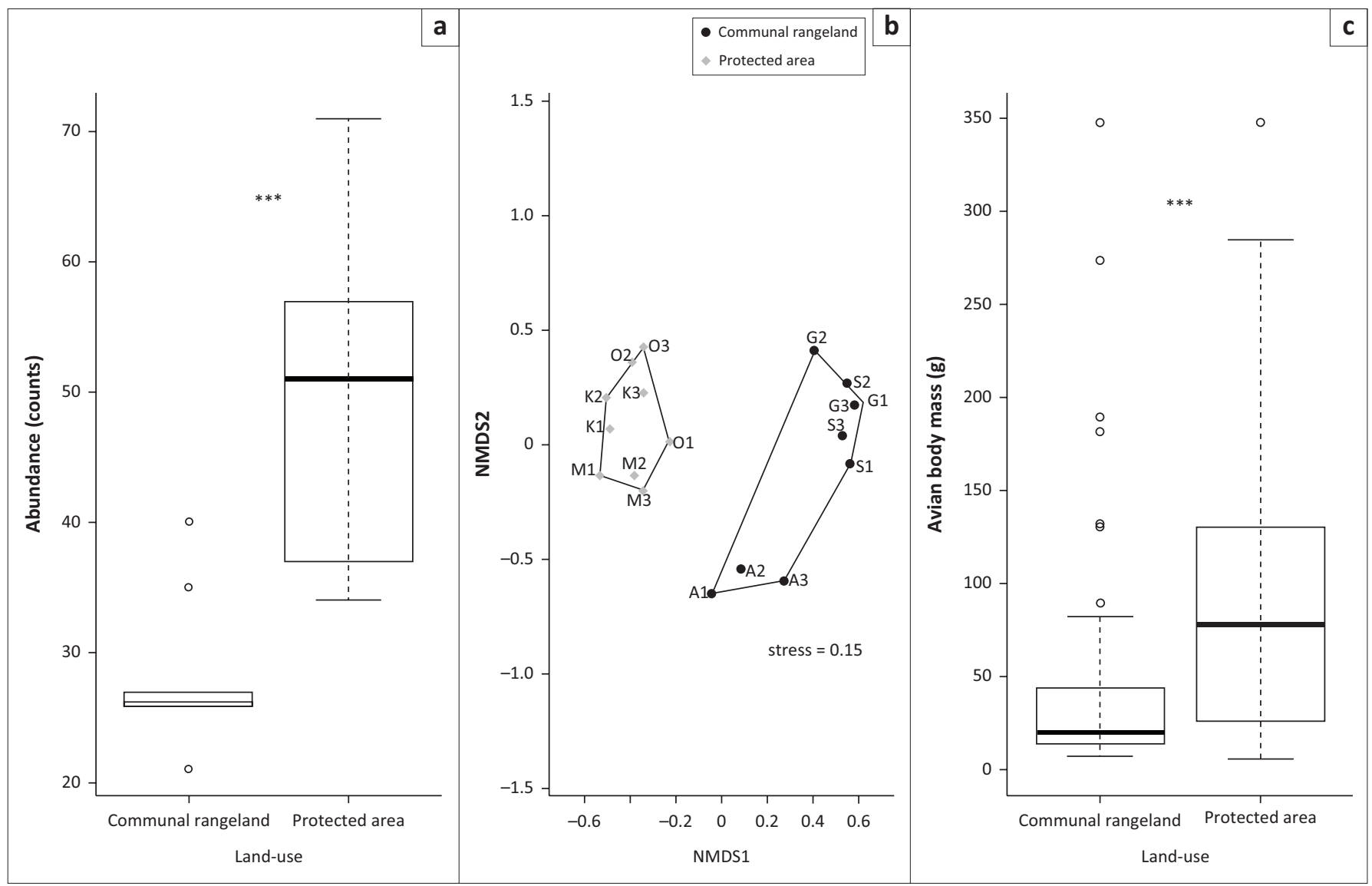

A, Athol; G, Gottenburg; S, Shorty; K, Kingfisherspruit; M, Manyeleti; O, Orpen; NMDS, non-metric multi-dimensional scaling.

$* * *, p<0.001$.

FIGURE 2: (a) Boxplot comparing the abundances (counts) of birds per transect survey between land-use types (protected areas vs. communal rangelands). (b) Non-metric multi-dimensional scaling ordination plot of bird assemblages in different land-use types. The stress value for the ordination was 0.15 , indicating that the projected distances in the ordination diagram were reliable. Each point represents one transect; different letters represent different sites. Numbers represent the three different transects of each site. (c) Boxplot comparing median body masses of birds recorded per transect between land-use types. Median body mass was calculated by pooling both bird surveys of each transect.

with grass height (Figure 8-A1). In addition, species richness was significantly inversely related to increased levels of woody plant density greater than $0.5 \mathrm{~m}$ in height, for both CRs and PAs (Table 1, Figure 9-A1). The abundance of birds was significantly higher in PAs than in CRs (Figure 2a; Table 2-A1). In addition, bird abundance was significantly inversely related to increased grass height (Figure 10-A1; Table 2-A1).

\section{Assemblage composition}

Of the 117 species recorded, 48 were common to both landuses, of which the most common species were the rattling cisticola (Cisticola chiniana), Cape turtle dove (Streptopelia capicola) and white-browed scrub robin (Cercotrichas leucophrys). Forty-four species were unique to PAs, most commonly Senegal lapwing (Vanellus lugubris), Swainson's spurfowl (Pternistes swainsonii) and magpie shrike (Corvinella melanoleuca). In contrast, only 25 species were unique to CRs (Figure 3; Table 3-A1), most commonly white-bellied sunbird (Cinnyris talatala), western cattle egret (Bubulcus ibis) and sombre greenbul (Andropadus importunus). Avian species assemblage composition differed substantially between PAs and CRs (Figure 2b). The PERMANOVA showed that PAs and CRs had significantly different avian species assemblages (global $R=0.335 ; p<0.001$ ). 


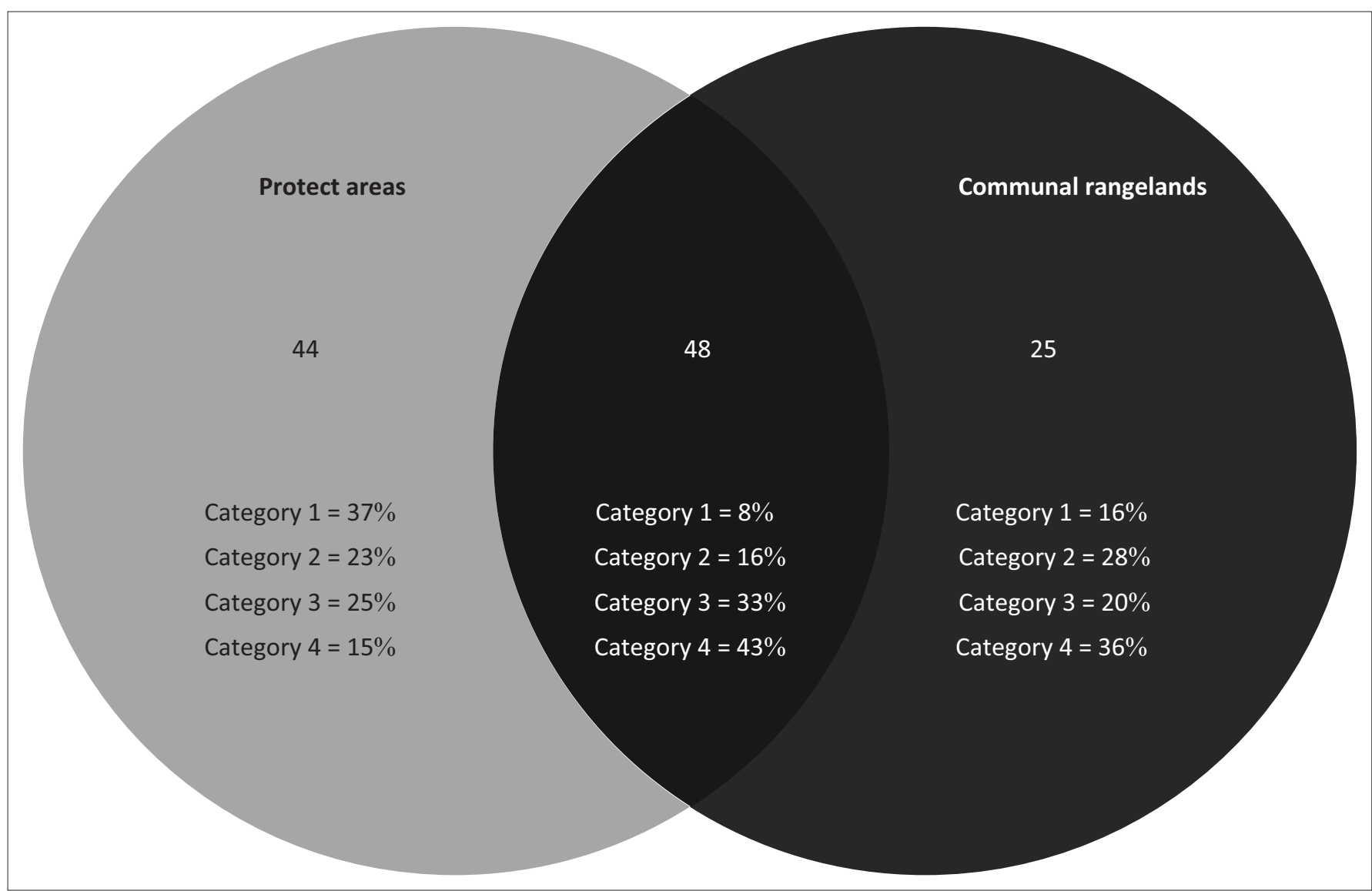

FIGURE 3: Venn diagram showing the number of bird species that are shared and are unique to protected areas and communal rangelands. Additionally, the percentage of birds in each habitat preference category is shown for each land-use type. Category $1=$ birds that associate with open grassy areas; category $2=$ birds that associate with open grassy and closed-canopy wooded areas, but have a greater affinity for open grassy areas; category $3=$ birds that associate with open grassy areas and closedcanopy wooded areas, but have a greater affinity for closed-canopy wooded areas and category $4=$ birds that associate with closed-canopy wooded habitats.

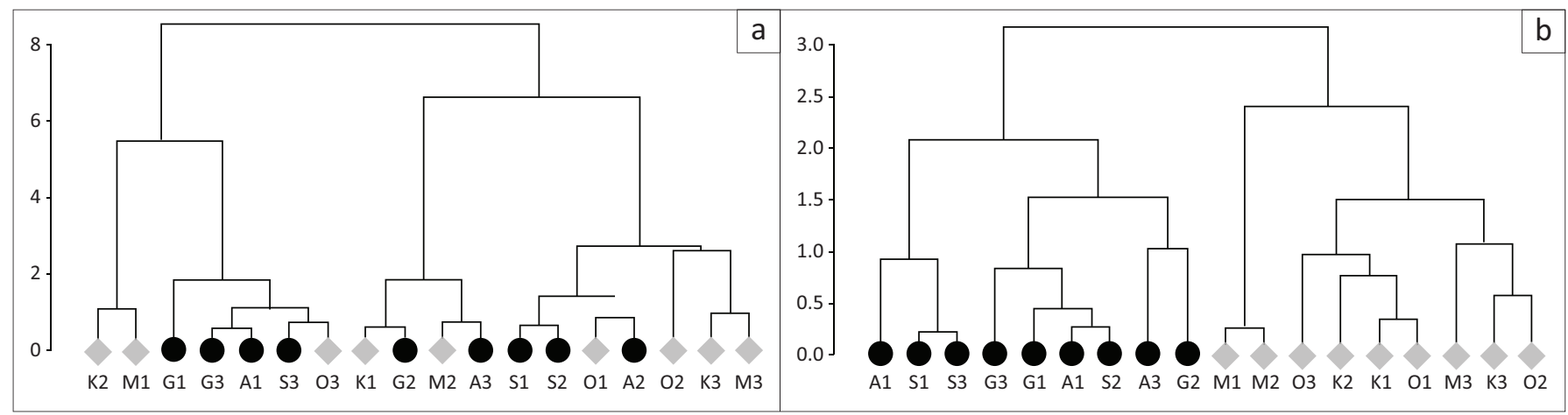

A, Athol; G, Gottenburg; S, Shorty; K, Kingfisherspruit; M, Manyeleti; and O, Orpen. Numbers represent the three different transects of each site.

FIGURE 4: Result of the cluster analysis based on (a) feeding guild composition and (b) habitat preference category compositions. Groupings were based on Euclidean distances between transects. Protected areas are indicated with grey diamonds and communal rangelands are indicated with black circles.

An almost equal number of plant species were shared between PAs and CRs as were unique to either PAs or CRs (Figure 11-A1). However, of the 88 species unique to either PAs or CRs, 30 were recorded only once.

\section{Functional composition}

The median body mass of birds was greater in PAs than in CRs (Figure 2c, Table 4-A1). No clear compositional grouping of transects by land-use types (PAs vs. CRs) existed based on feeding guild compositions (Figure 4a). In contrast, cluster analysis grouped communities from PAs and CRs into two distinct clusters based on bird habitat preference composition (Figure 4b). Protected areas had higher proportions of category 1 birds (open grassy habitat specialists, e.g. Senegal lapwing [Vanellus lugubris] and African pipit [Anthus cinnamomeus]), while CRs had higher proportions of category 4 birds (closed-canopy thicket/woodland habitat specialists, e.g. white-browed scrub robin [Cercotrichas leucophrys] and sombre greenbul [Andropadus importunus]) (Figure 12-A1). Indeed, of the species unique to PAs, $37 \%$ were category 1 birds, while in CRs this was only 16\% (Figure 3). In contrast, PAs had $15 \%$ and CRs had $36 \%$ of their unique species classified as category 4 species. 


\section{Vegetation structure}

Tree density was significantly higher in CRs (mean = 3050 trees per hectare) than in PAs (mean $=884$ trees per hectare) (chi-square $=5.62, p=0.018, d f=1$ ). However, maximum leaf table height did not differ between land-use types (chi-square $=0.42, p=0.52, d f=1$ ). Maximum leaf table height in CRs was $12.66 \mathrm{~cm} \pm 0.31$ (mean $\pm \mathrm{SE}$ ) and in PAs it was $13.23 \pm 0.43$.

\section{Discussion}

We show that even when habitat change outside PAs involves habitat degradation instead of habitat loss because of transformation, it can still affect bird assemblages. Bird assemblages in PAs were richer, with greater abundances and different composition than assemblages in adjacent CRs. In addition, PAs supported larger bodied species and birds of different habitat preference categories, although there were no differences in the composition of feeding guilds between PAs and CRs. The differences in bird assemblages inside and outside PAs indicate either a significant relationship between formal conservation designation and assemblage structure or reflect declines in the favourability of conditions outside PAs (e.g. homogenisation of vegetation structure). In the Kruger to Canyons Biosphere Reserve, within which this study was conducted, human settlements have expanded by $36 \%$, which has led to a $27 \%$ loss of intact savanna vegetation and a 30\% increase in thicket vegetation (Coetzer et al. 2010). This will have affected bird assemblage composition.

Floristically, areas within and outside the PAs surveyed here, are similar (Voysey 2018), yet structurally the areas outside the PAs have experienced significant levels of woody thickening over the last 70 years (Stevens et al. 2016), which has resulted in a homogenisation of the vegetation structure in CRs. Elsewhere, structural variation of both woody and grassy vegetation is the most important determinant of savanna avian assemblages (Hudson \& Bouwman 2007; Krook et al. 2007; Sirami et al. 2009; Skowno \& Bond 2003), and may explain why the more open and structurally heterogeneous vegetation of the PAs in this study supported a greater bird species richness, distinct species assemblage composition and a greater incidence of open habitat bird species.

The greater avian diversity seen within the structurally more diverse PAs may partially be because of the availability of more niches associated with variable vegetation structure (Hudson \& Bouwman 2007). The PAs showed more variation in grass height compared to CRs, where grass was constantly kept short, and showed little variation in grass height because of constant grazing by cattle in these areas (Figure 2-A1) (Voysey 2018). This may explain why increasing grass height had a positive impact on species richness outside PAs, but no effect within PAs: increasing grass height in CRs could provide new niches for birds, but more of the same niches in PAs. Other studies have shown that areas with heterogeneous grass height support more and different grassland bird species than areas that are heavily grazed to homogeneous short grass heights (Dias, Bastazini, \& Gianuca 2014; Jacoboski, Paulsen \& Hartz 2017).

Increased woody vegetation density resulted in declines in the proportion of birds that associate with open grassy areas (category 1) and an increase in the proportion of birds that associate with closed-canopy woody vegetation (category 4). The loss of large open grassy patches outside the PAs because of the corresponding increases in woody vegetation and its effect on homogenising vegetation structure with CRs may explain the observed differences in the proportions of habitat preference categories between the two land-uses. This is in accordance with other studies that have found that woody thickening results in losses of grassland bird species which require open vegetation patches, while benefiting woodland species (Sirami et al. 2009; Skowno \& Bond 2003). Indeed, closed-habitat specialists have increased across South Africa and its bordering countries: passerines that are open-savanna specialists have been declining, while closed-savanna specialists have increased across the region, particularly in the eastern parts of South Africa (Péron \& Altwegg 2015), where bush encroachment is considered a serious threat (Stevens et al. 2016).

Increased pressures on the avifauna (especially in the form of hunting) may have further contributed to the differences in bird assemblages inside and outside PAs. The CRs are extractive reserves for the surrounding villages, as such birds are actively hunted both with slingshots and traps (Vincent Khosa, pers. obs.; pers. comm., 18 January 2017). Elsewhere, hunting in communal areas has caused significant declines in bird numbers (Krook et al. 2007). It appears that people preferentially hunt for large-bodied ground nesters (surrogate species group 1, sensu Coetzee \& Chown 2016) (e.g. crested francolin [Peliperdix sephaena] and helmeted guineafowl [Numida meleagris]) as only two observations of this species group were made within CRs, compared to the 117 observations in PAs. Indeed, larger bodied species are usually targeted disproportionately by hunting (Coetzee \& Chown 2016; Cullen et al. 2000; Pimm et al. 2014). Thus, hunting pressure may not only contribute to a reduction in avian species richness and abundances, but may also explain why the median body mass of birds was higher in PAs than in CRs.

Our results suggest that, because of the reduced human pressures within their boundaries, the PAs in this study are acting as important population source areas for some bird species that are exploited for hunting in the CRs, and possibly also for open habitat bird species (Hansen 2011). However, the CRs also support a rich diversity of savanna bird species (Table 3-A1). Indeed, heavier degradation and more intensive land-use have much greater detrimental impacts on biodiversity (Greve et al. 2011; Newbold et al. 2015). Therefore, the contribution of these areas, along with other unprotected areas globally, to the conservation of birds should not be underestimated (Cox \& Underwood 2011). 
While our study assessed the ecological effectiveness of PAs, it did not assess effectiveness in the broader sense of the word. Overall effectiveness of PAs not only assesses PA contribution to biodiversity conservation, but also considers ecosystem services and social and cultural benefits to communities in and around PAs (Coad et al. 2008; Pringle 2017). Adjacent to the PAs considered in this study, community benefits of PAs are fairly limited; as a matter of fact, some communities incur costs as a result of the PAs (Anthony 2007; Spenceley \& Goodwin 2008; Swemmer, Mmethi \& Twine 2017). Therefore, ecological effectiveness does not automatically translate into other aspects of PA effectiveness. In a world of increasing population size and per capita food consumption, the need for agriculture, including pastoralism, has never been greater to ensure the well-being of rural communities. Hence, the need to ensure both biodiversity conservation and livelihoods is often considered in assessing PA effectiveness (Swemmer et al. 2017).

Upgrading existing protected areas has been suggested as one of the mechanisms by which both biodiversity conservation and livelihood goals can be addressed in and around PAs (Pringle 2017). Some of the eight principles for upgrading PAs are already, or could be, implemented in this area. For example conservation policies already incorporate elements of being long-term and local: government provides long-term funding, and some people from the Mnisi community are employed by businesses associated with the PAs (V. Khosa, pers. comm., 18 January 2017), and involving the youth could raise awareness among younger generations. However, the community remains fairly impoverished, and other principles would be more difficult to implement. These include upsizing the Kruger National Park (KNP) (Pringle 2017). Around the CRs sampled here, the number and extent of human settlements, and the density of people living in settlements, has grown substantially over the last three decades (Coetzer et al. 2010; Giannecchini, Twine \& Vogel 2007). Land remains very important for the livelihood of the local community. Therefore, it would be difficult to expand the KNP in this area because of possible wildlife-human conflicts (Anthony, Scott \& Antypas 2010). However, these CRs could be viewed as a matrix or buffer area that serves to reduce external pressures on the PA network (Pringle 2017). For example, although there are some changes in bird and plant functional groups, composition and structure between the CRs and PAs, many species are also retained, and this region probably serves as an important area for gene flow and population sustainability for these species. In summary, as upgrading the PA network in this instance might not be a viable option, continued efforts to engage local people from the surrounding areas may be extremely important to see the benefits of, and create ownership for, the PA network in the region (Pringle 2017). This may help to ensure that the wider regional portfolio of birds and their habitats are maintained, so that the entire area, not just the PAs, serves to represent bird biodiversity and helps ensure the persistence of viable populations into the future.
While we found that all measures of ecological effectiveness were higher in the PAs compared to surrounding CRs, other studies have found that some of these measures, such as species richness, are higher outside than inside PAs (Coetzee \& Chown 2016; Greve et al. 2011). This does not necessarily mean that these PAs are not performing well to represent and conserve biodiversity within their boundaries, but rather that measures of ecological effectiveness are context-and scale-dependent. For example Coetzee and Chown (2016) suggest that a higher observed bird richness outside the KNP is because of the increased vegetation productivity of croplands which experience year-round irrigation, supporting higher numbers of birds than the PA, which experiences large drops in productivity in the dry season. Greve et al. (2011) find higher richness of birds outside than inside one PA, but also significant decreases in specialist guilds, at the expense of generalist guilds, indicating that changes in ecological effectiveness should be considered as a product of all measures. Even PAs that were not necessarily established to protect all of the biodiversity of an area still function as valuable repositories for biodiversity conservation (Greve et al. 2011). Finally, scale can affect the direction of differences in diversity between regions: for example areas with high spatial and temporal beta diversity will show low diversity if measured at local scale, but high diversity if measured at regional scale (Chiarucci et al. 2012).

A number of limitations should be considered for this study. We have mainly attributed differences in bird assemblages in PAs and CRs to different land management types. We are confident that land-use plays an important role in explaining these differences. However, some differences in bird assemblages and vegetation characteristics of PAs and CRs may have been driven by the fact that animal densities differed between these landuse types (Voysey 2018), which was impossible to fully control in this study. Furthermore, our study was conducted in one location only; therefore, other regions or land-use types may have different outcomes (Coetzee \& Chown 2016; Greve et al. 2011). Additionally, we assessed impacts of degradation in only one location. Other regions may show different trends, depending on land-use changes and community characteristics (Coetzee \& Chown 2016; Greve et al. 2011). Finally, we assessed only mid-summer bird assemblages; winter and spring assemblages may show different responses to land-use. Of all the species we recorded, $17 \%$ were migrants.

\section{Conclusion}

In summary, landscape degradation, though not as extreme a process as landscape transformation, leads to changes in bird assemblages. Nevertheless, degraded habitats remain important habitats for a range of bird species, and their contribution to the protection of avian diversity should not be underestimated. 


\section{Acknowledgements}

The authors thank the South African National Parks and Mpumalanga Tourism and Parks Agency for providing them with access to the research sites within the protected areas. A special thanks to field rangers Thomas Rikombe and Happy Magena. Tribal leaders of the Mnisi Tribal Authority are thanked for granting access to the three communal rangeland sites. A special thanks to Vincent Khosa for his support as field assistant in the communal rangeland sites.

\section{Competing interests}

The authors declare that they have no financial or personal relationships that may have inappropriately influenced them in writing this article.

\section{Authors' contributions}

M.A.H. led all aspects of the project. The project was conceptualised by M.G., who was involved in all aspects of the project. M.D.V. contributed to experimental design, advice regarding the project, fieldwork and analyses. S.-L.J. contributed to the data. All authors contributed to the writing of the manuscript.

\section{Funding information}

This work was funded by the South African National Research Foundation (grant no. 98889 and 110734).

\section{Data availability statement}

Data is available on request from the corresponding author.

\section{Disclaimer}

The views and opinions expressed in this article are those of the author(s) and do not necessarily reflect the official policy or position of any affiliated agency of the authors.

\section{References}

Aitchison, J., 1982, 'The statistical analysis of compositional data', Journal of the Royal Statistical Society: Series B 44(2), 139-177. https://doi.org/10.1111/j.25176161.1982.tb01195.x

Andam, K.S., Ferraro, P.J., Pfaff, A., Sanchez-Azofeifa, G.A. \& Robalino, J.A., 2008 'Measuring the effectivness of protected area networks in reducing deforestation', Proceedings of the National Academy of Sciences of the United States of America 105(42), 16089-16094. https://doi.org/10.1073/pnas.0800437105

Anthony, B.P., 2007, 'The dual nature of parks: Attitudes of neighbouring communities towards Kruger National Park, South Africa', Environmental Conservation 34(3), 236-245. https://doi.org/10.1017/S0376892907004018

Anthony, B.P., Scott, P. \& Antypas, A., 2010, 'Sitting on the fence? Policies and practices in managing human-wildlife conflict in Limpopo province, South Africa', Conservation and Society 8(3), 225-240. https://doi.org/10.4103/0972 4923.73812

Balmford, A., Green, J.M.H., Anderson, M., Beresford, J., Huang, C., Naidoo, R. et al., 2015, 'Walk on the wild side: Estimating the global magnitude of visits to protected areas', PLoS Biology, 13(2), e1002074. https://doi.org/10.1371/journal. pbio.1002074

Barton, K., 2017, MuMIn: Multi-Model inference, R package, version 1.40.0., viewed 15 October 2017, from https://CRAN.R-project.org/package=MuMln

Bates, D., Maechler, M., Bolker, B. \& Walker, S., 2015, 'Fitting linear mixed-effects models using Ime4', Journal of Statistical Software 67(2015), 1-48. https://doi. org/10.18637/jss.v067.i01
Bibby, C., Jones, M. \& Marsden, S., 2000, Expedition field techniques: Bird surveys, BirdLife International, Cambridge.

Brose, U., Blanchard, J.L., Eklof, A., Galiana, N., Hartvig, M., Kalinkat, R.H.M.G. et al., 2017, 'Predicting the consequences of species loss using size-structured biodiversity approaches', Biological Reviews 92(2), 684-697. https://doi.org/ 10.1111/brv.12250

Burnham, K.P. \& Anderson, D.R., 2002, Model selection and mulitmodel inference, 2nd edn., Springer-Verlag, New York.

Caro, T., Gardner, T.A., Stoner, C., Fitzherbert, E. \& Davenport, T.R.B., 2009, 'Assessing the effectiveness of protected areas: Paradoxes call for pluralism in evaluating conservation performance', Diversity and Distributions 15(1), 178-182. https:// doi.org/10.1111/j.1472-4642.2008.00522.x

Chape, S., Harrison, J., Spalding, M. \& Lysenko, I., 2005, 'Measuring the extent and effectiveness of protected areas as an indicator for meeting global biodiversity targets', Philosophical Transactions of the Royal Society B 360(1454), 443-455. https://doi.org/10.1098/rstb.2004.1592

Chiarucci, A., Bacaro, G., Filibeck, G., Landi, S., Machcherini, S. \& Scoppola, A., 2012, 'Scale dependence of plant species richness in a network of protected areas', Biodiversity and Conservation 21(2), 503-516. https://doi.org/10.1007/s10531 011-0196-8

Chown, S.L., 2010, 'Temporal biodiversity change in transformed landscapes: A southern African perspective', Philosophical Transactions of the Royal Society $B$ 365(1558), 3729-3742. https://doi.org/10.1098/rstb.2010.0274

Coad, L., Campbell, A., Miles, L. \& Humphries, K., 2008, The costs and benefits of protected areas for livelihoods: A review of the current literature, Working paper, UNEP World Conservation Monitoring Centre, Cambridge, UK.

Coetzee, B.W.T. \& Chown, S.L., 2016, 'Land-use change promotes avian diversity at the expense of species with unique traits', Ecology and Evolution 6(21), 7610-7622. https://doi.org/10.1002/ece3.2389

Coetzee, B.W.T., Gaston, K.J. \& Chown, S.L., 2014, 'Local scale comparisons of biodiversity as a test for global protected area ecological performance: A meta-analysis', PLoS One 9(8), e105824. https://doi.org/10.1371/journal.pone. 0105824

Coetzer, K.L., Erasmus, B.F.N., Witkowski, E.T.F. \& Bachoo, A.K., 2010, 'Land-cover change in the Kruger to Canyons Biosphere Reserve (1993-2006): A first step towards creating a conservation plan for the subregion, South African Journal of Science 106(7/8), 1-10. https://doi.org/10.4102/sajs.v106i7/8.221

Cox, R.L. \& Underwood, E.C., 2011, 'The importance of conserving biodiversity outside protected areas in Mediterranean ecosystems', PLoS One 6(1), e14508. https://doi.org/10.1371/journal.pone.0014508

Cullen, L., Bodmer, R.E. \& Pádua, C.V., 2000, 'Effects of hunting in habitat fragments of the Atlantic forests, Brazil', Biological Conservation 95(1), 49-56. https://doi. org/10.1016/S0006-3207(00)00011-2

Dias, R.A., Bastazini, V.A.G. \& Gianuca, A.T., 2014, 'Bird-habitat associations in costal rangelands of southern Brazil', Iheringia Série Zoologia 104(1), 200-208. https:// doi.org/10.1590/1678-476620141042200208

Dudley, N., Hockings, M. \& Stolton, S., 2010, 'Precious places: Getting the arguments right', in S. Stolton \& N. Dudley (eds.), Arguments for protected areas: Multiple benefits for conservation and use, pp. 253-265, Earthscan Ltd, London.

Foley, J.A., DeFries, R., Asner, J.P., Barford, C., Bonan, G., Carpenter, S.R. et al., 2005 'Global consequences of land use', Science 309(5737), 570-574. https://doi. org/10.1126/science.1111772

Gardner, T. A., Caro, T., Fitzherbert, E.B., Banda, T. \& Lalbhai P., 2007, 'Conservation value of multiple-use areas in East Africa', Conservation Biology 21(6), 1516-1525. https://doi.org/10.1111/j.1523-1739.2007.00794.x

Gaston, K.J., Charman, K., Jackson, S.F., Armsworth, P.R., Bonn, A., Briers, R.A. et al., 2006, 'The ecological effectiveness of protected areas: The United Kingdom', Biological Conservation 132(1), 76-87. https://doi.org/10.1016/j.biocon.2006. 03.013

Gaston, K.J., Jackson, S.F., Cantú-Salazar, L. \& Cruz-Piñón, G., 2008, 'The ecological performance of protected areas', Annual Review of Ecology, Evolution, and Systematics 39(1), 93-113. https://doi.org/10.1146/annurev. ecolsys.39.110707.173529

Geldmann, J., Barnes, M., Coad, L., Craigie, I.D., Hockings, M. \& Burgess, N.D., 2013 'Effectivness of terrestrial protected areas in reducing habitat loss and population declines', Biological Conservation 16(1), 230-238. https://doi.org/10.1016/j. biocon.2013.02.018

Gerland, P., Raftery, A.E., Ševčíková, H., Li, N., Gu, D., Spoorenberg, T. et al., 2014 , 'World population stabilization unlikely this century', Science 346(6206), 234-239. https://doi.org/10.1126/science.1257469

Giannecchini, M., Twine, W. \& Vogel, C., 2007, 'Land-cover change and humanenvironment interactions in a rural cultural landscape in South Africa', The Geographical Journal 173(1), 26-42. https://doi.org/10.1111/j.1475-4959.2007. 00227.x

Gotelli, N. \& Colwell, R.K., 2001, 'Quantifying biodiversity: Procedures and pitfalls in the measurement and comparison of species richness', Ecology Letters 4(4), 379-391. https://doi.org/10.1046/j.1461-0248.2001.00230.x

Gray, C.L., Hill, S.L., Newbold, T., Hudson, L.N., Borger, L., Contu, S. et al. 2016, 'Local biodiversity is higher inside than outside terrestrial protected areas worldwide', Nature Communications 7, 12306. https://doi.org/10.1038/ ncomms12306

Greve, M., Chown, S.L., Van Rensburg, B.J., Dallimer, M. \& Gaston, K.J., 2011, 'The ecological effectiveness of protected areas: A case study for South African birds', Animal Conservation 14(3), 295-305. https://doi.org/10.1111/j.14691795.2010.00429.x 
Greve, M., Gaston, K.J., Van Rensburg, B.J. \& Chown, S.L., 2008, 'Environmental factors, regional body size distributions and spatial variation in body size of local avian assemblages', Global Ecology and Biogeography 17(4), 514-523. https:// avian assemblages', Global Ecology and Bioge
doi.org/10.1111/j.1466-8238.2008.00388.x

Hansen, A.J., 2011, 'Contribution of source-sink theory to protected area science', in J. Liu, V. Hall, A. Morzillo \& J. Wiens (eds.), Sources, sinks and sustainability across landscapes, pp. 339-360, Cambridge University Press, Cambridge.

Hockey, P.A.R., Dean, W.R.J. \& Ryan, P.G., 2005, Roberts birds of southern Africa, Trustees of the John Voelcker Bird Book Fund, Cape Town.

Hoffmann, M., Hilton-Taylor, C., Angulo, A., Bohm, M., Brooks, T.M., Butchart, S.H et al,, 2010. 'The impact of conservation on the status of the world's vertebrates' Science 330(6010), 1503-1509. https://doi.org/10.1126/science.1194442

Hudson, A. \& Bouwman, H., 2007, 'Different land-use types affect bird communities in the Kalahari, South Africa', African Journal of Ecology 45(3), 423-430. https://doi. org/10.1111/j.1365-2028.2006.00750.x

Jackson, S.F., Evans, K.L. \& Gaston, K.J., 2009, 'Statutory protected areas and avian species richness in Britain', Biodiversity and Conservation 18(8), 2143-2151. https://doi.org/10.1007/s10531-009-9578-6

Jacoboski, L.I., Paulsen, R.K. \& Hartz, S.M., 2017, 'Bird-grassland associations in protected and non-protected areas in southern Brazil', Perspectives in Ecology and Conservation, 15(2), 109-114. https://doi.org/10.1016/j.pecon Ecology and 2017.05 .002

James, A.N., Gaston, K.J. \& Balmford, A., 1999, 'Balancing the earth's accounts', Nature 401(6751), 323-324. https://doi.org/10.1038/43774

Jamison, S.-L. 2017, 'Unlocking bird-tree relationships: Exploring biogeographical patterns across southern Africa', MSc thesis, Dept. of Plant and Soil Sciences, University of Pretoria.

Joppa, L.N., Loarie, S.R. \& Pimm, S.L., 2008, 'On the protection of "protected areas", Proceedings of the National Academy of Sciences of the United States of America 105(18), 6673-6678. https://doi.org/10.1073/pnas.0802471105

Joppa, L.N. \& Pfaff, A., 2009, 'High and far: Biases in the location of protected areas' PLOS One 4(12):e8273. https://doi.org/10.1371/journal.pone.0008273

Krook, K., Bond, W.J. \& Hockey, P.A.R., 2007, 'The effect of grassland shifts on the avifauna of a South African savanna', Ostrich 78(2), 271-279. https://doi. org/10.2989/OSTRICH.2007.78.2.24.104

Laurance, W.F., Camargo, J.L.C., Luizão, R.C.C., Laurance, S.G., Pimm, S.L., Bruna, E.M et al., 2011, 'The fate of Amazonian forest fragments: A 32-year investigation', et al., 2011, 'The fate of Amazonian forest fragments: A 32-year investigation',
Biological Conservation 144(1), 56-67. https://doi.org/10.1016/j.biocon.2010. 09.021

Laurance, W.F., Useche, D.C., Rendeiro, J., Kalka, M., Bradshaw, C.J., Sloan, S.P. et al, 2012, 'Averting biodiversity collapse in tropical forest protected areas', Nature 2012, Averting biodive

Longcore, T. \& Rich, C., 2004, 'Ecological light pollution', Frontiers in Ecology and the Environment 2(4), 191-198. https://doi.org/10.1890/1540-9295(2004)002 [0191:ELP]2.0.CO;2

Margules, C.R. \& Pressey, R.L., 2000, 'Systematic conservation planning', Nature 405(6783), 243-254. https://doi.org/10.1038/35012251

McCulloch, C.E., 1996, 'An introduction to generalized linear mixed models', Applied Statistics in Agriculture 10(1), 1-17. https://doi.org/10.4148/2475-7772.1314

Meiri, S. \& Thomas, G., 2007, 'The geography of body size - challenges of the interspecific approach', Global Ecology and Biogeography 16(6), 689-693. https:// doi.org/10.1111/j.1466-8238.2007.00343.x

Miller, D.L., 2017, Distance: Distance sampling detection function and abundance estimation, R package, version 0.9.7., viewed 03 August 2017, from https:// CRAN.R-project.org/package=Distance

Mpumalanga Department of Agriculture and Land Administration, 1997, Institute for Soil, Climate and Water - Soils clay layer for Mpumalanga part of the Kruger National Park (KNP), received from SANParks GIS Lab, September 2018.

Mucina, L. \& Rutherford, M.C. (eds.), 2006, The vegetation of South Africa, Lesotho and Swaziland, Strelitzia 19, Pretoria.

Newbold, T., Hudson, L.N., Hill, S.L.L., Contu, S., Lysenko, I., Senior, R.A. et al. 2015 'Global effects of land use on local terrestrial biodiversity', Nature 520(7545), 45-50. https://doi.org/10.1038/nature14324

Oksanen, J., Blanchet, F.G., Friendly, M., Kindt, R., Solymos, P., Henry, M. et al., 2017 Vegan: Community ecology package, R package, version 2.4-3., viewed 18 July 2017, from https://CRAN.R-project.org/package=vegan
Palmer, A.R. \& Bennett, J.E., 2013, 'Degradation of communal rangelands in South Africa towards an improved understanding to inform policy', African Journal of Range and Forage Science 30(1-2), 57-63. https://doi.org/10.2989/10220119.2 Range and
013.779596

Péron, G. \& Altwegg, R., 2015, 'Twenty-five years of change in southern African passerine diversity: Nonclimatic factors of change', Global Change Biology 21(9), 3347-3355. https://doi.org/10.1111/gcb.12909

Pimm, S. L., Jenkins, C.N., Abell, R., Brooks, T.M., Gittleman, J.L., Joppa, L.N. et al., 2014, 'The biodiversity of species and their rates of extinction, distribution, and protection', Science 344(6187), 987-999. https://doi.org/10.1126/ science.1246752

Pringle, R.M., 2017, 'Upgrading protected areas to conserve wild biodiversity', Nature 546(7656), 91-99. https://doi.org/10.1038/nature22902

R Core Team, 2018, R: A language and environment for statistical computing, version 3.5.0, computer program, R Foundation for Statistical Computing, Vienna, Austria.

Rayner, L., Lindenmayer, D.B., Wood, J.T., Gibbons, P. \& Manning, A.D., 2014, 'Are protected areas maintaining bird diversity?', Ecography 37(1), 43-53. https://doi. org/10.1111/j.1600-0587.2013.00388.x

Roser, M. \& Ritchie, H., 2018, 'Yields and land use in agriculture', in OurWorldinData. org, viewed 29 November 2018, from https://ourworldindata.org/yields-andland-use-in-agriculture

Rouget, M., Jonas, Z., Cowling, R.M., Desmet, P.G., Driver, A., Mucina, L. et al. 2006, 'Ecosystem status and protection levels of vegetation types', in L. Mucina \& M.C. Rutherford (eds.), The vegetation of South Africa, Lesotho and Swaziland, pp. 724-737, Strelitzia 19, Pretoria.

Sinclair, A.R., Mduma, S.A. \& Arcese, P., 2002, 'Protected areas as biodiversity benchmarks for human impact: Agriculture and the Serengeti avifauna', Proceedings: Biological Sciences 269(1508), 2401-2405. https://doi.org/10.1098/ rspb.2002.2116

Sirami, C., Seymour, C., Midgley, G. \& Barnard, P., 2009, 'The impact of shrub encroachment on savanna bird diversity from local to regional scale', Diversity and Distributions 15(6), 948-957. https://doi.org/10.1111/j.1472-4642.2009.00612.x

Skowno, A.L. \& Bond, W.J., 2003, 'Bird community composition in an actively managed savanna reserve, importance of vegetation structure and vegetation composition', Biodiversity and Conservation 12(11), 2279-2294. https://doi. org/10.1023/A:1024545531463

Spenceley, A. \& Goodwin, H., 2008, 'Nature-based tourism and poverty alleviation: Impacts of private sector and parastatal enterprises in and around Kruger National Park, South Africa', Current Issues in Tourism 10(2-3), 255-277, https:// doi.org/10.2167/cit305.0

Stevens, N., Erasmus, B.F., Archibald, S. \& Bond, W.J., 2016, 'Woody encroachment over 70 years in South African savannahs: Overgrazing, global change or extinction aftershock?', Philosophical Transactions of the Royal Society B 371(1703) 20150437. https://doi.org/10.1098/rstb.2015.0437

Swemmer, L., Mmethi, H. \& Twine, W., 2017, 'Tracing the cost/benefit pathway of protected areas: A case study of the Kruger National Park, South Africa', Ecosystem Services 28, 162-172. https://doi.org/10.1016/j.ecoser.2017.09.002

Thomas, L., Buckland, S.T., Rexstad, E.A., Laake, J.L., Strindberg, S. \& Hedley, S.L., 2010, 'Distance software: Design and analysis of distance sampling surveys for
estimating population size', Journal of Applied Ecology 47(5), 5-14. https://doi. estimating population size', Journal of $A p p$
org/10.1111/j.1365-2664.2009.01737.x

Van den Boogaart, K.G., Tolosana, R. \& Bren, M., 2014, Compositions: Compositional data analysis, R package, version 1.40-1, viewed 22 September 2017, from https://CRAN.R-project.org/package=compositions

Voysey, M.D., 2018, 'The influence of wildlife and livestock herbivore assemblages on grazing lawn flora', MSc thesis, Dept. of Plant and Soil Sciences, University of Pretoria.

Waldron, A., Mooers, A.O., Miller, D.C., Nibbelink, N., Redding, D., Kuhn, T.S. et al., 2013, 'Targeting global conservation funding to limit immediate biodiversity declines', Proceedings of the National Academy of Sciences of the United States of America 10(29), 12144-12148. https://doi.org/10.1073/pnas.1221370110

Wegge, P., Odden, M., Pokharel, C.P. \& Storaas, T., 2009, 'Predator-prey relationships and responses of ungulates and their predators to the establishment of protected areas: A case study of tigers, leopards and their prey in Bardia National Park, Nepal', Biological Conservation 142, 189-202. https://doi.org/10.1016/j. biocon.2008.10.020

Zuur, A., leno, E.N., Walker, N., Saveliev, A.A. \& Smith, G.M., 2009, Mixed effects models and extensions in ecology with $R$, Springer-Verlag, New York. 


\section{Appendix 1}

TABLE 1-A1: Livestock densities of the three communal rangeland sites. Data on livestock densities were obtained from the State Veterinary Department, originally collected by the Mnisi Community Programme, and represent a fiveyear mean \pm standard error (SE) (2012-2016)

\begin{tabular}{ll}
\hline Communal rangeland site & Animal density (TLU ha \\
\hline Athol $)$ cattle and goats \\
Gottenburg & $1.17 \pm 0.0 .3$ \\
Shorty & $0.78 \pm 0.04$ \\
\hline
\end{tabular}

Note: Goats represented on average only $2.76 \%$ of the Total Livestock Units ha-1.

ha, hectare; Total Livestock Units.

TABLE 2-A1: Results from the generalised linear mixed effects models comparing avian abundances between land-use types (protected areas versus communal rangelands), while taking vegetation structural variables (maximum grass leaf table height and the density of woody vegetation greater than 0.5 meters) into consideration.

\begin{tabular}{|c|c|c|c|c|c|c|c|}
\hline Variable & Level & Estimate & SE & $z$-value & $p$-value & SD & Variance \\
\hline \multicolumn{8}{|l|}{ Fixed effects } \\
\hline Intercept & - & 4.486 & 0.147 & 30.387 & $* * *$ & - & - \\
\hline Land-use & Protected $>$ Rangeland & 0.605 & 0.085 & 7.451 & $* * *$ & - & - \\
\hline Max grass height & - & -2.498 & 1.464 & -3.407 & $* * *$ & - & - \\
\hline
\end{tabular}
Radom effects

$\underline{(1 \mid \text { Site) }}$

0.0165

Note: The results represent the best subset model, selected based on AIC values. Abundances represent pooled abundances of both bird surveys conducted for each transect.

$\mathrm{SE}$, standard error; SD, standard deviation; ns, not significant.

$* * *, p<0.001$.

TABLE 3-A1: Cumulative counts of birds surveyed per land-use type in alphabetical order

\begin{tabular}{|c|c|c|c|}
\hline Species & Communal rangeland & Protected area & Total abundance \\
\hline Acacia Pied Barbet - Tricholaema leucomelas & 1 & 1 & 2 \\
\hline African Cuckoo - Cuculus gularis & 0 & 1 & 1 \\
\hline African Dusky Flycatcher - Muscicapa adusta & 4 & 7 & 11 \\
\hline African (Blue-billed) Firefinch - Lagonosticta rubricata & 0 & 1 & 1 \\
\hline African Grey Hornbill - Tockus nasutus & 0 & 7 & 7 \\
\hline African Pipit - Anthus cinnamomeus & 0 & 16 & 16 \\
\hline Amur Falcon - Falco amurensis & 0 & 11 & 11 \\
\hline Arrow-marked Babbler - Turdoides jardineii & 1 & 23 & 24 \\
\hline Ashy Flycatcher - Muscicapa caerulescens & 0 & 3 & 3 \\
\hline Bearded Scrub Robin - Sheppardia gunningi & 0 & 1 & 1 \\
\hline Bearded Woodpecker-Dendropicos namaquus & 1 & 2 & 3 \\
\hline Black Cuckooshrike - Campephaga flava & 1 & 1 & 2 \\
\hline Black-backed Puffback - Dryoscopus cubla & 5 & 8 & 13 \\
\hline Black-chested Snake Eagle - Circaetus pectoralis & 1 & 0 & 1 \\
\hline Black-crowned Tchagra - Tchagra senegala & 1 & 10 & 11 \\
\hline Black-headed Oriole - Oriolus larvatus & 2 & 4 & 6 \\
\hline Blacksmith Lapwing - Vanellus armatus & 0 & 6 & 6 \\
\hline Blue Waxbill - Uraeginthus angolensis & 4 & 3 & 7 \\
\hline Bronze-winged Courser - Rhinoptilus chalcopterus & 0 & 1 & 1 \\
\hline Brown-crowned Tchagra - Tchagra australis & 15 & 19 & 34 \\
\hline Brown-headed Parrot - Poicephalus cryptoxanthus & 0 & 2 & 2 \\
\hline Brown-hooded Kingfisher - Halcyon albiventris & 1 & 2 & 3 \\
\hline BruBru - Nilaus afer & 2 & 4 & 6 \\
\hline Buff-spotted Flufftail - Sarothrura elegans & 0 & 3 & 3 \\
\hline Burchell's Coucal - Centropus burchelli & 2 & 1 & 3 \\
\hline Burchell's Starling - Lamprotornis australis & 0 & 22 & 22 \\
\hline Burnt-necked Eremomela - Eremomela usticollis & 0 & 2 & 2 \\
\hline Cape Glossy Starling - Lamprotornis nitens & 14 & 2 & 16 \\
\hline Chestnut-backed Sparrow-lark - Eremopterix leucotis & 0 & 5 & 5 \\
\hline Chinspot Batis - Batis molitor & 29 & 27 & 56 \\
\hline Cinnamon-breasted Bunting - Emberiza tahapisi & 1 & 10 & 11 \\
\hline Common Scimitarbill - Rhinopomastus cyanomelas & 1 & 0 & 1 \\
\hline
\end{tabular}


TABLE 3-A1 (Continues...): Counts of birds surveyed per land-use type in alphabetical order.

Species Communal rangeland

Crested Barbet - Trachyphonus vaillantii

Crested francolin - Peliperdix sephaena

Crowned Lapwing - Vanellus coronatus

Dark-capped Bulbul - Pycnonotus tricolor

Dideric Cuckoo - Chrysococcyx caprius

Dusky Lark - Pinarocorys nigricans

Egyptian Goose - Alopochen aegyptiacus

Emerald-spotted Wood Dove - Turtur chalcospilos

European Bee-eater-Merops apiaster

European Roller - Coracias garrulus

Fork-tailed Drongo - Dicrurus adsimilis Communal rangeland

\begin{tabular}{|c|c|}
\hline Protected area & Total abundance \\
\hline 2 & 2 \\
\hline 31 & 34 \\
\hline 2 & 2 \\
\hline 0 & 1 \\
\hline 1 & 2 \\
\hline 16 & 17 \\
\hline 2 & 2 \\
\hline 20 & 56 \\
\hline 2 & 17 \\
\hline 29 & 30 \\
\hline 2 & 7 \\
\hline 7 & 30 \\
\hline 0 & 1 \\
\hline 2 & 2 \\
\hline 0 & 2 \\
\hline 1 & 1 \\
\hline 16 & 23 \\
\hline 3 & 5 \\
\hline 4 & 7 \\
\hline 1 & 1 \\
\hline 8 & 8 \\
\hline 2 & 4 \\
\hline 0 & 1 \\
\hline 0 & 2 \\
\hline 27 & 27 \\
\hline 10 & 13 \\
\hline 0 & 3 \\
\hline 0 & 2 \\
\hline 23 & 55 \\
\hline 26 & 27 \\
\hline 37 & 37 \\
\hline 0 & 1 \\
\hline 0 & 1 \\
\hline 16 & 16 \\
\hline 7 & 9 \\
\hline 4 & 4 \\
\hline 2 & 2 \\
\hline 64 & 104 \\
\hline 25 & 45 \\
\hline 26 & 26 \\
\hline 7 & 8 \\
\hline 1 & 3 \\
\hline 1 & 1 \\
\hline 1 & 1 \\
\hline 4 & 4 \\
\hline 2 & 2 \\
\hline 0 & 5 \\
\hline 0 & 5 \\
\hline 5 & 10 \\
\hline 54 & 54 \\
\hline 0 & 8 \\
\hline 5 & 6 \\
\hline 2 & 6 \\
\hline 3 & 3 \\
\hline 1 & 1 \\
\hline 3 & 4 \\
\hline 1 & 1 \\
\hline 0 & 1 \\
\hline 1 & 1 \\
\hline 9 & 12 \\
\hline 0 & 1 \\
\hline
\end{tabular}

Total abundance

Golden-breasted Bunting - Emberiza flaviventris

Golden-tailed Woodpecker - Campethera abingoni

Great Spotted Cuckoo - Clamator glandarius

Greater Honeyguide - Indicator indicator

Green Wood-Hoopoe-Phoeniculus purpureus

Grey Go-away-bird - Corythaixoides concolor

Grey-backed Camaroptera - Camaroptera brevicaudata

Grey-headed Bushshrike - Malaconotus blanchoti

Hadeda Ibis - Bostrychia hagedash

Helmeted Guineafowl - Numida meleagris

Jacobin Cuckoo - Oxylophus jacobinus

Jameson's Firefinch - Lagonosticta rhodopareia

Klaas's Cuckoo - Chrysococcyx klaas

Laughing Dove - Streptopelia senegalensis

Lesser Grey Shrike - Lanius minor

Lesser Masked Weaver - Ploceus intermedius

Little Bee-eater-Merops pusillus

Long-billed Crombec - Sylvietta rufescens

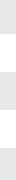

1

1
0
36

0

3

0

0

2

2

2

0

3

3

2

32

Long-tailed Paradise Whydah - Vidua paradisaea 1

Magpie Shrike - Corvinella melanoleuca 0

Marico Sunbird - Cinnyris mariquensis 1

Namaqua Dove - Oena capensis

$\begin{array}{ll}\text { Natal Spurfowl - Pternistes natalensis } & 0 \\ \text { Orange-breasted Bushshrike-Telophorus sulfureopectus } & 2\end{array}$

Purple Roller - Coracias naevia

Purple-crested Turaco - Musophaga porphyreolopha 0

Rattling Cisticola-Cistiocola chinianus $\quad 40$

Red-backed Shrike - Lanius collurio $\quad 20$

Red-billed Buffalo Weaver - Bubalornis niger 0

Red-billed Oxpecker - Buphagus erythrorhynchus

Red-billed Quelea - Quelea quelea

Red-breasted Swallow - Hirundo semirufa

Red-chested Cuckoo - Cuculus solitarius

Red-crested Korhaan - Eupodotis ruficrista

Red-eye Dove - Streptopelia semitorquata

Red-faced Mousebird - Urocolius indicus

Rufous-naped Lark - Mirafra africana

Sabota Lark - Mirafra sabota

Senegal Lapwing - Vanellus lugubris

Sombre Greenbul - Andropadus importunus

Southern Black Tit - Parus niger

Southern Boubou - Laniarius ferrugineus

Southern Carmine Bee-eater - Merops nubicoides

Southern Double-collared Sunbird - Cinnyris chalybea

Southern Grey-headed Sparrow - Passer diffusus

Southern Ground-Hornbill - Bucorvus leadbeateri

Southern Masked Weaver - Ploceus velatus

Southern Red-billed Hornbill - Tockus erythrorhynchus

Southern Yellow-billed hornbill - Tockus leucomelas

Speckled Mousebird - Colius striatus

1
2

0

0

0

0

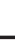


TABLE 3-A1 (Continues...): Counts of birds surveyed per land-use type in alphabetical order.

\begin{tabular}{|c|c|c|c|}
\hline Species & Communal rangeland & Protected area & Total abundance \\
\hline Steppe Buzzard - Buteo vulpinus & 1 & 0 & 1 \\
\hline Stierling's Wren-Warbler - Calamonastes stierlingi & 2 & 3 & 5 \\
\hline Striped Kingfisher - Halcyon chelicuti & 0 & 1 & 1 \\
\hline Swainson's Spurfowl - Pternistes swainsonii & 0 & 38 & 38 \\
\hline Swee Waxbill - Estrilda melanotis & 0 & 3 & 3 \\
\hline Tawny Eagle - Aquila rapax & 0 & 1 & 1 \\
\hline Tawny-flanked Prinia - Prinia subflava & 1 & 2 & 3 \\
\hline Temminck's Courser - Cursorius temminckii & 0 & 9 & 9 \\
\hline Terrestrial Brownbul - Phyllastrephus terrestris & 1 & 0 & 1 \\
\hline Violet-eared Waxbill - Granatina granatina & 1 & 0 & 1 \\
\hline Western Cattle Egret - Bubulcus ibis & 10 & 0 & 10 \\
\hline White-backed Vulture - Gyps africanus & 0 & 1 & 1 \\
\hline White-bellied Sunbird - Cinnyris talatala & 20 & 0 & 20 \\
\hline White-browed Robin-chat - Cossypha heuglini & 1 & 1 & 2 \\
\hline White-crested Helmetshrike - Prionops pulmatus & 11 & 6 & 17 \\
\hline Willow Warbler - Phylloscopus trochilus & 4 & 0 & 4 \\
\hline Woodland Kingfisher - Halcyon senegalensis & 0 & 14 & 14 \\
\hline Yellow-bellied Greenbul - Chlorocichla flaviventrius & 1 & 0 & 1 \\
\hline Yellow-breasted Apalis - Apalis flavida & 2 & 3 & 5 \\
\hline Yellow-fronted Canary - Serinus mozambicus & 23 & 17 & 40 \\
\hline
\end{tabular}

TABLE 4-A1: Results from generalised linear mixed effects models comparing median avian body mass between land-use types (protected areas versus communal rangelands), while taking vegetation structure variables (maximum grass leaf table height and the density of woody vegetation greater than 0.5 meters) into consideration.

\begin{tabular}{lcccccc}
\hline Variable Level & Estimate & SE & $z$-value & $p$-value & SD & Variance \\
\hline Fixed effects & & & & & & \\
Intercept - & 3.190 & 0.187 & 17.042 & $* * *$ & - & - \\
$\begin{array}{l}\text { Land-use Protected }> \\
\quad 1.194\end{array}$ & 0.196 & 6.106 & $* * *$ & - & - \\
$\quad$ Rangeland & & & & & & \\
Radom effects & & & & & &
\end{tabular}

\section{Radom effects}

(1|Site) $0.00 \quad 0.00$

Note: The model presented represents the best subset model, selected based on Akaike information criterion values. Median body mass was calculated by pooling both bird surveys of each transect.

$\mathrm{SE}$, standard error; SD, standard deviation; ns, not significant.

$* * *, p<0.001$

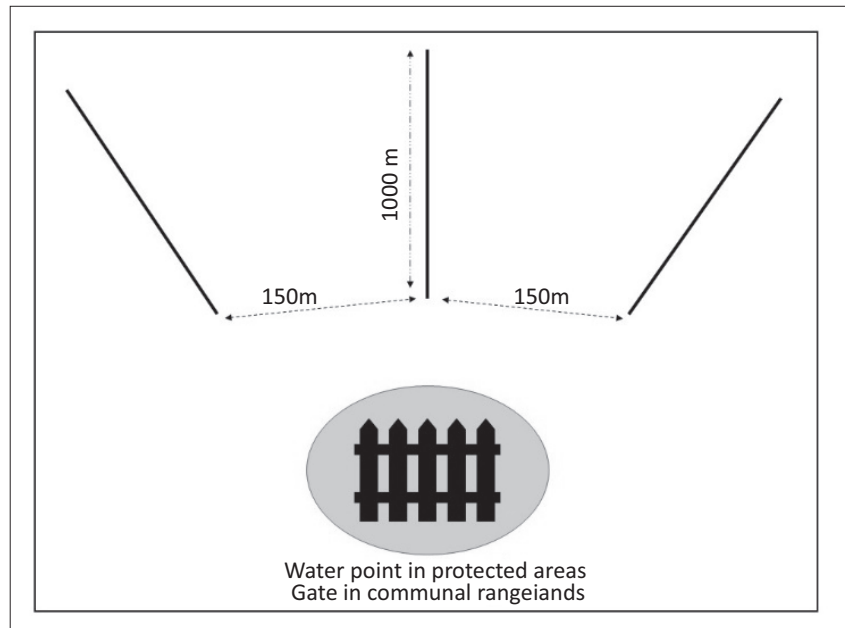

$\mathrm{m}$, metres.

FIGURE 1-A1: Diagram showing layout of three transects at each site. At each site, the three transects were set up within 40 meters from a water point (in protected areas) or a livestock camp gate (in communal rangelands). Transects started 150 meters from one another and radiated out from on another. Transects were 1000 meters in length.

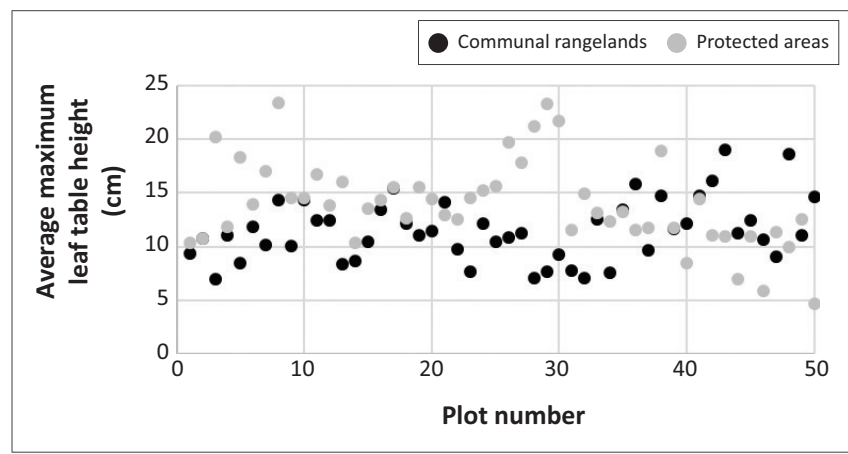

$\mathrm{cm}$, centimetres.

FIGURE 2-A1: Scatter plot showing the relationship of average maximum leaf table per plot number of each land-use type (protected areas versus communal rangelands). Plot number increases with distance from water source (protected area) or gate (communal rangelands)

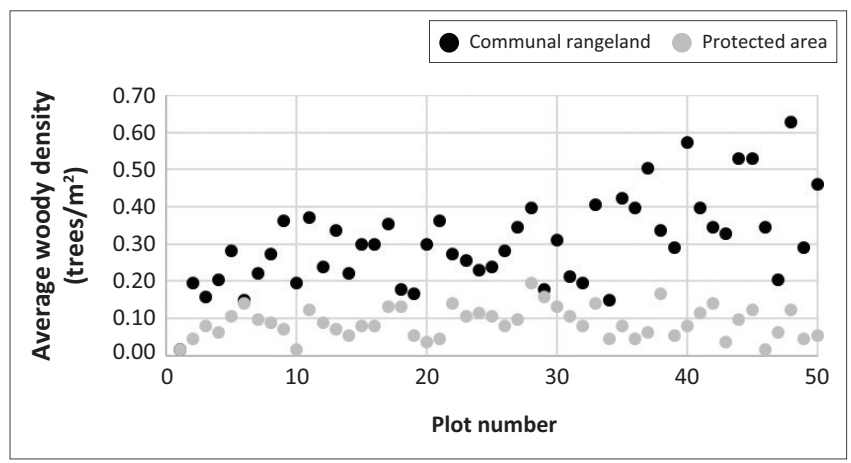

$\mathrm{m}$, metres

FIGURE 3-A1: Scatter plot showing the average woody density of trees $>0.5 \mathrm{~m}$ per plot number of each land-use type (protected areas versus communal rangelands) Plot number increases with distance from water source (protected area) or gate (communal rangelands). 

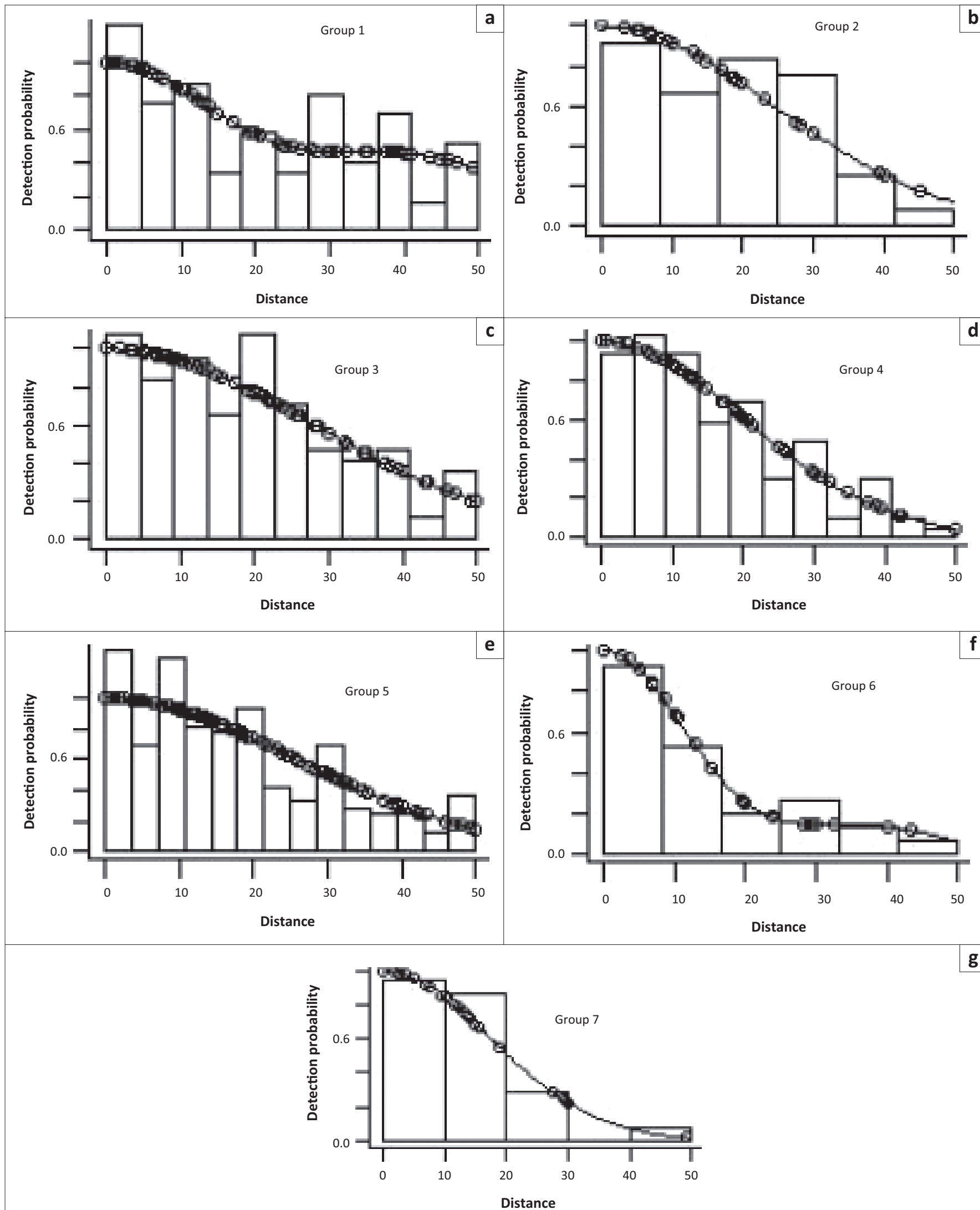

FIGURE 4-A1: Detectability curves for the seven surrogate bird species groups fit for protected areas. Surrogate group numbers are indicated in the top right of each figure. (a) Group 1 (large-bodied, ground nesters), (b) group 2 (small to medium bodied, mixed feeders, frugivores, hole nesters), (c) group 3 (small to medium bodied, granivores, mainly platform nesters), (d) group 4 (small to medium bodied, parasitic breeders or cup nesters, insectivores, nectarivores), (e) group 5 (small to medium bodied, mainly insectivores, mixed feeders, mixed breeders), (f) group 6 (small bodied, granivores, cup nesters) and (g) group 7 (medium bodied, insectivore/frugivores, mainly hole nesters). See Coetzee and Chown. (2016:2610-2622) for more details. 

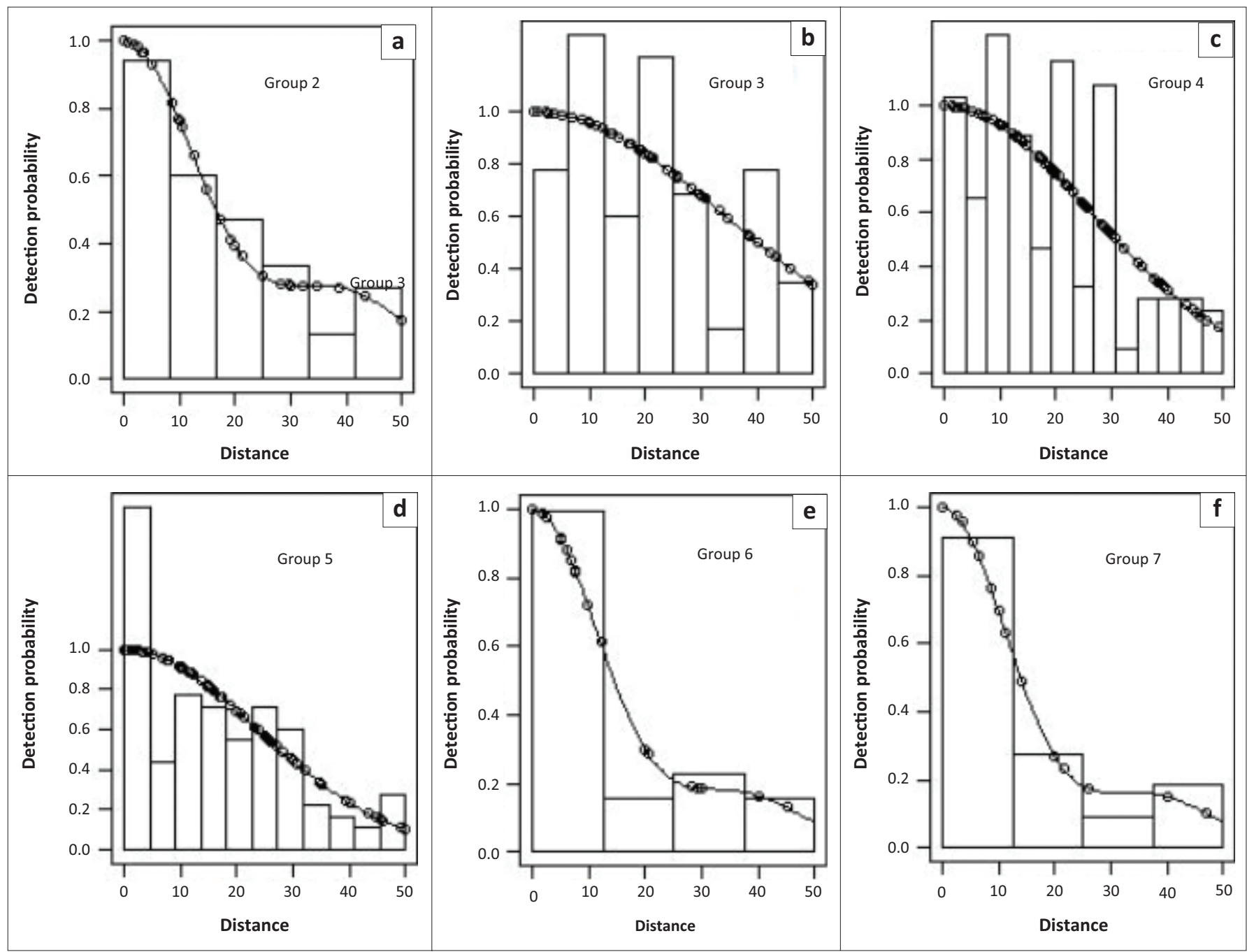

FIGURE 5-A1: Detectability curves for six of the seven surrogate bird species groups fit for communal rangelands. A detectability curve could not be fit for surrogate species (a) group 1 (large-bodied, ground nesters) as only two observations were made for this group in communal rangelands. Surrogate species groups are indicated in the top right of each figure. (b) Group 2 (small to medium bodied, mixed feeders, frugivores, hole nesters), (c) group 3 (small to medium bodied, granivores, mainly platform nesters), (d) group 4 (small to medium bodied, parasitic breeders or cup nesters, insectivores, nectarivores), (e) group 5 (small to medium bodied, mainly insectivores, mixed feeders, mixed breeders), (f) group 6 (small bodied, granivores, cup nesters) and (g) group 7 (medium bodied, insectivore/frugivores, mainly hole nesters).
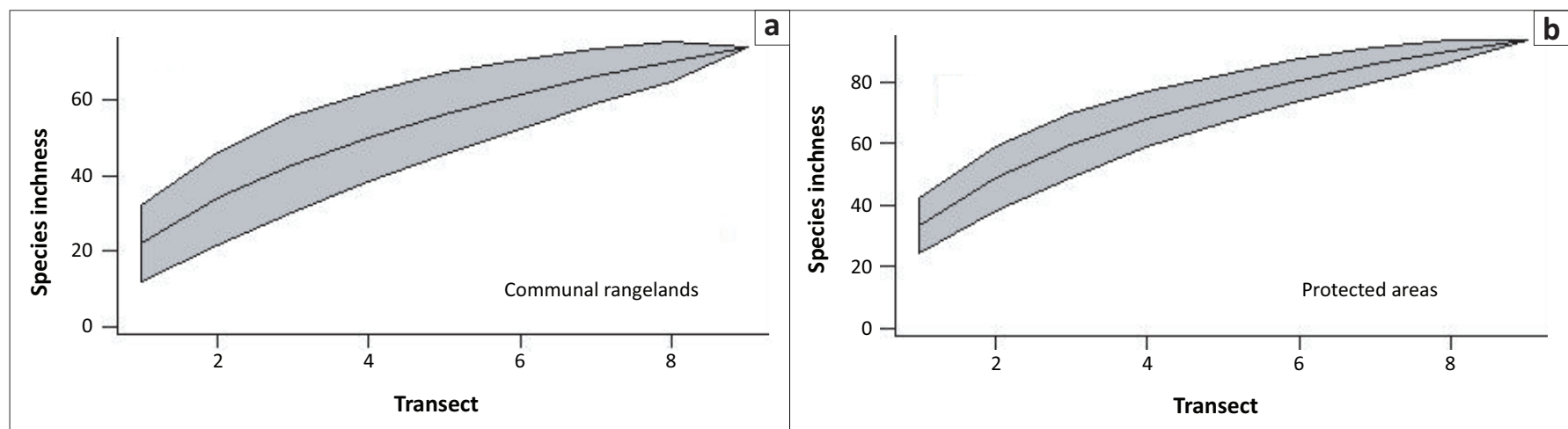

FIGURE 6-A1: Transect-based species accumulation curves using the random method, which assigns transects in a random order to quantify sampling adequacy, for (a) the nine transects in communal rangelands and (b) the nine transects in protected areas. Grey shading represents the $95 \%$ confidence interval for the extrapolated richness. 


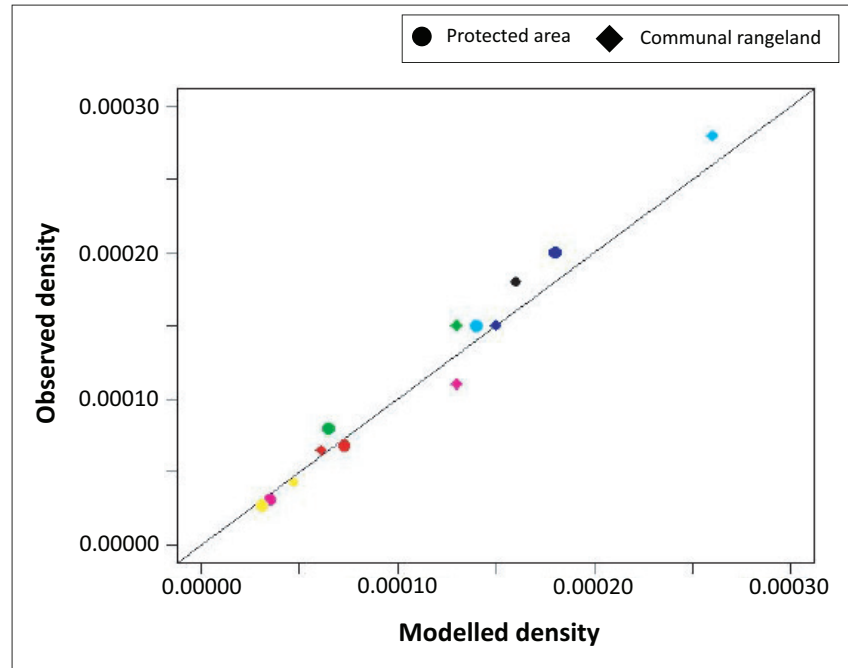

FIGURE 7-A1: The relationship between the observed and modelled bird densities in protected areas and communal rangelands for seven surrogate species groups after Coetzee et al. (2016). Black represents surrogate bird species group 1, red - group 2, green - group 3, blue - group 4, turquoise group 5, pink - group 6, and yellow - group 7. See Figure 5-A1 for the definition of groups. The two different land-use types are indicated by different symbols, as shown in the legend. The diagonal line with a slope of one to one shows the hypothetical line of best fit if observed density = modelled density. (Pearson's $r$ $=0.989 ; p<0.001$ )

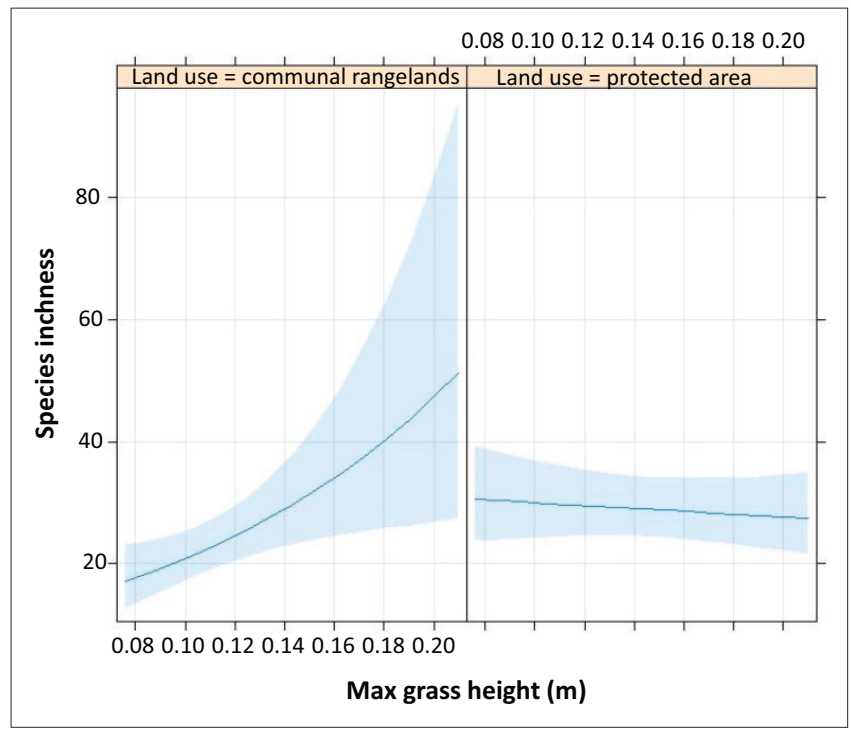

FIGURE 8-A1: Interaction plot showing the effects of maximum leaf table height (proxy for grass height), on avian species richness in different land-use types (protected areas versus communal rangelands). Light blue shading represents the $95 \%$ confidence interval for the fitted model.

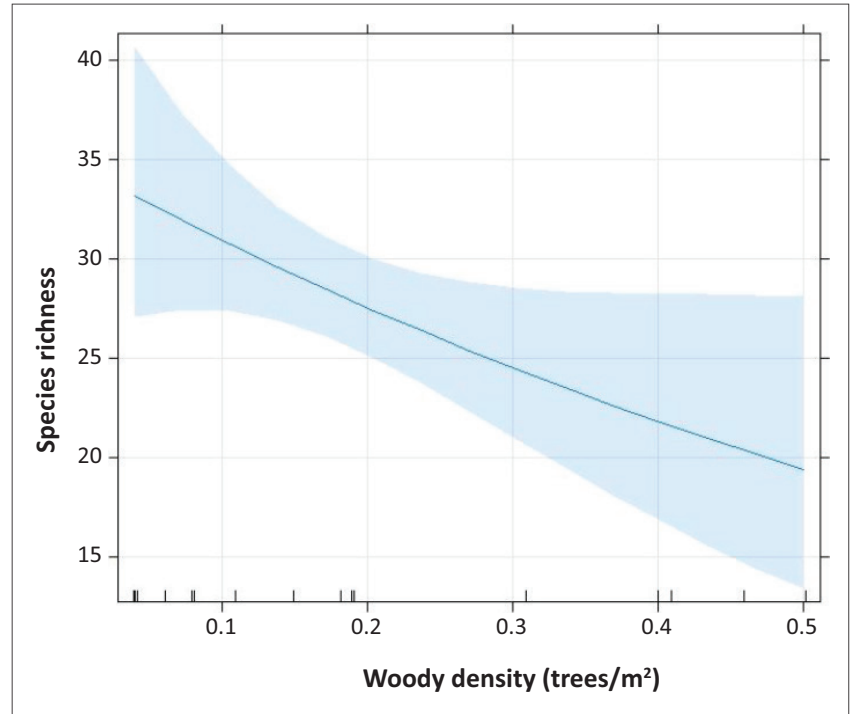

FIGURE 9-A1: Effects plot showing how avian species richness is affected by the density of woody vegetation above 0.5 meters in height. Light shaded blue represents the $95 \%$ confidence interval for the fitted model.

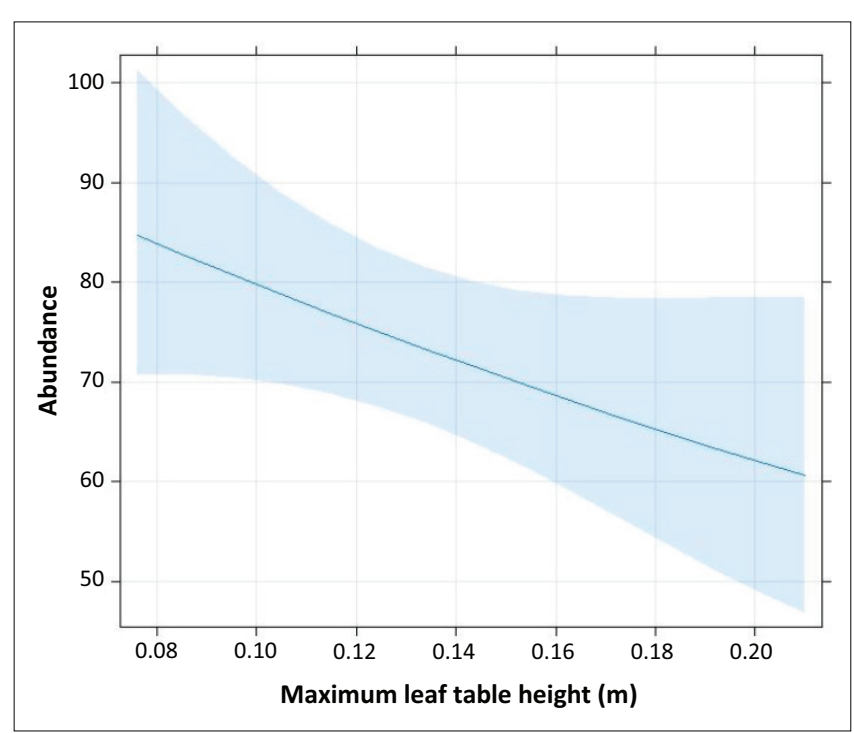

FIGURE 10-A1: Effects plot showing the relationship between avian abundance and maximum leaf table height (proxy for grass height). Abundances represent pooled abundances of both bird surveys conducted for each transect. Light shaded blue represents the $95 \%$ confidence interval for the fitted model. 


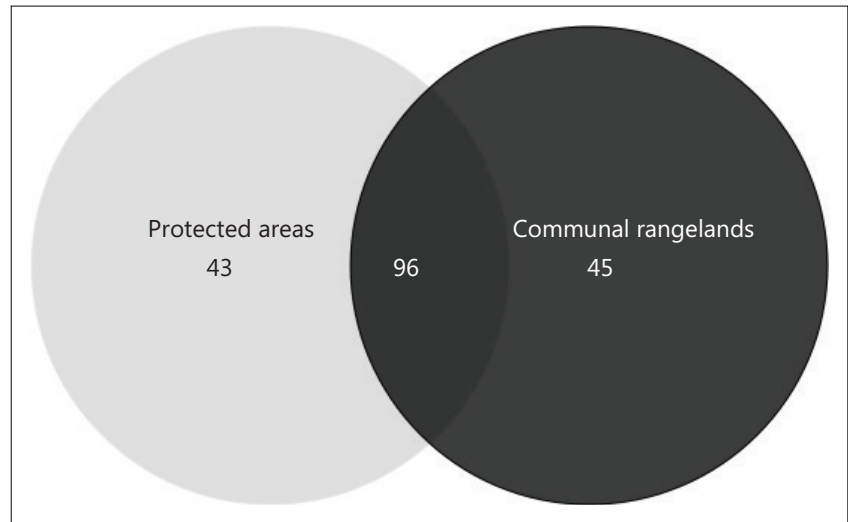

FIGURE 11-A1: A Venn diagram showing the number of plant (trees, grass and forb) species shared between and unique to protected areas and communal rangelands.

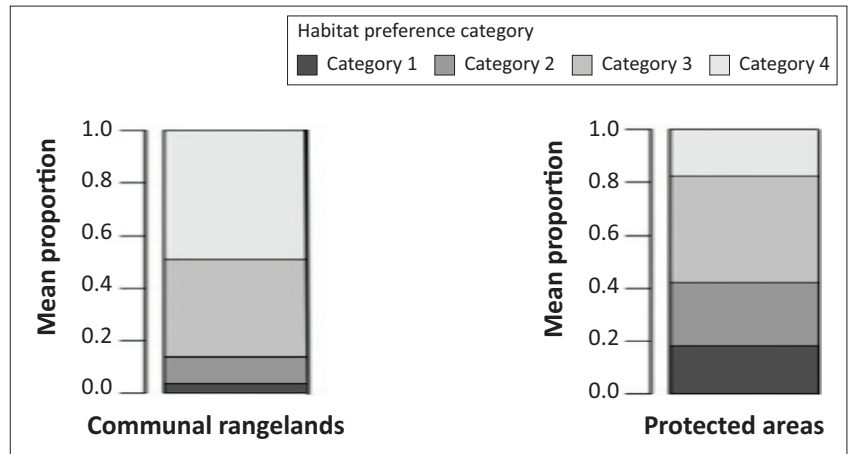

FIGURE 12-A1: The compositional mean of each habitat preference category between the two land-uses (protected areas versus communal rangelands). Category $1=$ birds that associate with open grassy areas, category $2=$ birds that associate with open grassy and closed canopy wooded areas, but have a greater affinity for open grassy areas, category $3=$ birds that associate with open grassy areas and closed canopy wooded areas, but have a greater affinity for closed canopy wooded areas and category $4=$ birds that associate with closed canopy wooded habitats. 